\title{
Tekstil Tasarımına Ekolojik Bir Yaklaşım: Lyocell Üzerine Doğal Boyama ve Eko Baskı
}

\author{
An Ecological Approach to Textile Design: Natural Dyeing and Eco Printing on Lyocell \\ Özge Özen, Tekstil ve Moda Tasarımı Anasanat Dalı, Güzel Sanatlar Enstitüsü, Dokuz Eylül Üniversitesi \\ Özlenen Erdem İșmal, Tekstil ve Moda Tasarımı Bölümü, Dokuz Eylül Üniversitesi
}

Özet

$\mathrm{Bu}$ araştırmada çevre dostu bir yaklaşımla tasarım, teknik ve estetiğin bir arada kullanıldığı deneysel bir çalıșma yapılmıștır. Tekstil, tasarım ve moda sektörlerinde sürdürülebilir ekolojik çalıșmalar konusunda artan farkındalıkla birlikte çeșitli doğal boya uygulamaları da güncel hale gelmiştir. Genel bir kanı olarak, doğal boya uygulamalarında daha iyi sonuçlar elde etmek için çoğunlukla yün ve ipek gibi protein esaslı liflerin kullanılması gerektiği düşünülmektedir. Gerçekleştirilen çalışmada ise çevre dostu, yapay ve selüloz esaslı rejenere bir lif olan Lyocell üzerine doğal boyama ve bitkileri şablon gibi kullanarak baskı uygulamaları yapılmıștır. Soğan kabuğu, zerdeçal, kök boya, nar kabuğu, endüstriyel bir yan ürün olan prina gibi doğal boyar madde kaynakları, potasyum alüminyum sülfat (șap), demir II sülfat, bakır II sülfat, kalay klorür gibi mordan maddeleri ile birlikte kullanılmıștır. Sistematik bir yaklaşımla en iyi uygulama koșulları ve sonuçlar belirlendikten sonra bitkilerle birlikte mümkün olan en düşük miktarlarda mordan maddeleri kullanılarak gayet net, canl, keskin kenarlı ve etkileyici görsel efektler elde edilmiştir. Birbirinden tamamen farklı, özgün ve tekrar edilemeyen bu desenler giysi tasarımları șeklinde sunulmuştur.

Anahtar Sözcükler: Doğal boyama, eko baskl, Lyocell, Tencel, mordan, sürdürülebilirlik, atık.

Akademik disipin(ler)/alan(lar): Tekstil ve moda tasarımı, tekstil boya ve baskı teknolojisi.

\begin{abstract}
In this research, an experimental study was conducted in which design, technique and aesthetics were combined with an environmentally friendly approach. With increasing awareness of sustainable ecological studies in the textile, design and fashion sectors, various natural dye applications have also become popular. It is usually thought that protein-based fibers such as wool and silk should be used mostly for better results in natural dye applications. In the study carried out, natural dyeing and printing applications using plants as a stencile were performed on Lyocell, an environmentally friendly, regenerated cellulosic man-made fiber. Sources of natural dyes such as onion skin, turmeric, madder, pomegranate peel, prina, an industrial by-product, were used in conjunction with mordants such as potassium aluminum sulfate (alum), iron II sulfate, copper II sulfate and tin chloride. Very clear, vivid, sharp-edged and impressive visual effects were generated by using the possible minimum amount of mordants with plants after determination of optimal application conditions and results through a systematic approach. These completely different, unique and unrepeatable patterns were presented as clothing designs.
\end{abstract}

Keywords: Natural dyeing, eco print, Lyocell, Tencel, mordant, sustainability, waste.

Academical disciplines/fields: Textile and fashion design, textile dyeing and printing technology.

- $\quad$ Sorumlu Yazar: Özge Özen, Tekstil ve Moda Tasarımı Anasanat Dalı, Güzel Sanatlar Enstitüsü, Dokuz Eylül Üniversitesi

- $\quad$ Adres: Dokuz Eylül Üniversitesi, Tınaztepe Yerleșesi, Adatepe Mah. Doğuş Cad. No:09, 35390 Buca, İzmir.

- e-posta: ozgeozen3535@gmail.com

- ORCID: 0000-0001-5145-6663

- Cevrimiçi yayın tarihi: 21.06 .2021

- doi: $10.17484 /$ yedi.863763 


\section{Giriş}

Gelişen teknoloji ve çevre dostu yaklaşımlarla birlikte ortaya çıkan yeni bakış açıları, tekstillerin de değişik şekillerde tasarım ve üretimlerine yol açmaktadır. Günümüzde gelinen noktada bilim, teknoloji ve tasarımın birlikte ele alınması kaçınılmaz bir hale gelmiş olup disiplinler arası çalışmalar büyük önem kazanmıştır.

“Tüketicilerin, ön yargı ve alışkanlıklarını değiştirmeleriyle ilgili kabule ve isteğe bağlı olarak tasarımlar, estetik kavramlar, eko kavramlar, malzeme seçimleri ve bakım alışkanlıklarının değişime uğraması öngörülebilir" (İșmal ve Yıldırım, 2011, s. 13).

Bilinçli tüketicilerin artmasıyla birlikte çevre yükü azaltılmış ürünlerin tasarımı önem kazanmaktadır. Ancak, bu noktada artan gereksinimler, yeni bakış açıları ve değişen estetik anlayışların da etkisiyle tekstillerin farklı şekillerde tasarım ve üretimleri gündeme gelmiş durumdadır. Dolayısıyla, birbiriyle etkileșim halinde olan birçok etkeni göz önüne almaları ve çok yönlü düşünmeleri gereken tasarımcılara önemli görevler düşmektedir.

Endüstriyel ürünlerin tasarlanıp üretilmeleri için, üretim süreçlerinin ve teknolojilerinin daha çevreci olmalarına çalışılmakta ve çeşitli tasarım modelleri planlanmaktadır. Çevreye duyarlı tasarım (Design for environment-DfE) yaklaşımı bunlardan biridir. Çevreye duyarlı tasarım aynı zamanda Ekotasarım veya Yeşil Tasarım olarak da adlandırılmaktadır. Bu yaklaşım, bir ürünün tüm yaşam döngüsünün önceden ve ekolojik ölçütlere uygun şekilde sistematik olarak tasarlanmasıdır. (İşmal vd., 2011, s. 10)

Birçok ülkede sürdürülebilirlik bilinci ile yapılan yenilikçi tasarım projeleri önem kazanmaya başlamıştır. Buna bir örnek olarak Textile Futures Research Center (TFRC) verilebilir. Eko tekstiller üzerine çalışan bu merkez; Central Saint Martins Collage of Art\&Design (CSM), Chelsea Collage of Art and Design (CCW) ve University of the Arts London (UAL)'daki araştırmacılarından oluşmakta ve tekstillerin gelecekte daha nasıl sürdürülebilir olabileceği konusunda yoğun çalışmalar yapmaktadırlar. Stratejileri ise, sürdürülebilir tasarım anlayışında bilim ve teknolojiyi kullanmaktır (İşmal ve Yıldırım, 2011, s. 11).

Geleneksel olarak geçmişten günümüze kadar kullanılagelmiş olan doğal boyama yöntemlerinin günümüzde sorgulandığı, gözden geçirildiği, bir kısım uygulamaların ise teknolojik gelişmelerle desteklenmiş yenilikçi yaklaşımlar șekline dönüştüğü söylenebilir. Bu bağlamda, doğal boyaların ve bitkiler gibi yenilenebilir doğal kaynakların renklendirme/desenlendirmede kullanılması hem çevre dostu yönü hem de estetik ve sanatsal olarak birbirinden özgün baskı tasarımlarının elde edilebilmesi açısından tekstil ve moda sektöründe oldukça ilgi çekici bir yöntemdir. Tüm dünyada doğal boyaların canlandırılması, kullanımlarının yaygınlaştırılması ve yeni kaynakların bulunması konusunda yoğun araştırmalar bulunmaktadır.

Bunun yanında Yeșil tekstillerin araştırmalarına yönelik çalıșmalarda UV koruması, antimikrobiyal, alev geciktirici ve sivrisinek kovucu gibi işlevsel özellikler kazandırma ve renklendirme için çeşitli bitki bazlı özlerin uygulanması güncel hale gelmiștir. Tekstil kimyasallarının bitki özleri kullanılarak işlenmesi, çevre dostu tekstillerin geliştirilmesine yardımcı olmakla birlikte tarımsal atıklara veya kalıntılara değer katmaktadır (Basak, Chattopadhyay \& Samanta, 2014, s. 264).

Doğal boyalar tekstil, kozmetik, boyama, mürekkepler, tarım, güneş pilleri, $\mathrm{pH}$ indikatörü, tıp vd. gibi geniş bir uygulama alanına sahiptir (Adeel, Rehman, Rafi, Zia \& Zuber, 2019, s. 402).

"Bazı doğal boyalar, antimikrobiyal, antialerjik, antiviral ve antioksidan özellikler gibi fonksiyonel aktivitelere sahiptir. Bunların birçoğu ayrıca mor ötesi (UV) ışığa karşı koruyucu bir etkiye sahiptir. Örneğin tanen bakımından zengin nar kabuğu özleri UV bölgesinde güçlü emilim göstermiştir” (Adeel vd., 2018, s. 3).

Bu çalışmadaki uygulamalarda kullanılan Tencel ${ }^{T M}$ Lyocell, yenilenebilir bir kaynak olan odun hamurundan yapılmıș, insan yapımı rejenere selülozik esaslı çevre dostu bir liftir. Sürdürülebilir bir lif olan Tencel ${ }^{T M}$ Lyocell üretiminde kullanılan tüm organik çözücüler ve emisyonların büyük bir kısmı geri kazanılarak yeniden kullanılır (Tencel ${ }^{\mathrm{TM}}$, t.y.).

Sertifikalı Tencel ${ }^{T M}$ Lyocell lifleri biyolojik olarak \%100 parçalanabilir. Bu eko kumaş, doğal nefes alabilirliğe ve pamuğa göre \%50 daha fazla nem emilimine sahiptir. Temelde doğal bir hammadde olduğu için aynı zamanda \%100 organik olan bu çevreye duyarlı süreç Avrupa Birliği tarafından Avrupa Çevre Ödülü de dahil olmak üzere birçok ödüle layık görülmüştür $\left(\right.$ Tencel $^{\mathrm{TM}}$, t.y.). 
Kaynakçaya bakıldığında, bitkilerin çeşitli kısımlarını doğrudan doğruya kumaş üzerine temas ettirerek desenlendirme konusunda yapılmış tasarım ve deneysel çalışmaların yeterli sayıda olmadığı, eko baskı tekniğinin günümüzde daha çok ipek, yün gibi protein esaslı kumașlar üzerinde denenmiș olduğu ve genel olarak bu kumaşlar üzerinde en iyi sonucu verdiği şeklinde bir kanı olduğu gözlemlenmektedir. Var olan genel görüşün aksine bu çalışmada ise, bu teknik daha önce üzerinde çok az çalışılmış, insan yapısı rejenere selüloz esaslı ve çevre dostu bir lif olan Lyocell kumaş üzerinde uygulanmıștır. Tasarım, teknik, estetik, yaratıcılık ve ekoloji birlikteliğginde sistematik bir yaklaşımla yapılan deneysel çalıșmada insan yapısı selülozik lif üzerinde en iyi renk ve eko baskı etkilerinin elde edilmesi amaçlanmıştır. Lyocell kumaş üzerine doğal boyamalar ve bitkileri şablon gibi kullanarak baskı uygulamaları yapılmıştır. Soğan kabuğu, zerdeçal, kök boya, nar kabuğu, endüstriyel bir yan ürün olan prina gibi doğal boyar madde kaynakları, metal mordanlar (potasyum alüminyum sülfat (șap), demir II sülfat, bakır II sülfat, kalay klorür) ile birlikte kullanılmıștır. Net, canlı, keskin kenarlı ve etkileyici görsel efektler elde etmek amacıyla sistematik bir yaklaşımla deneysel bir çalışma gerçekleştirilmiştir. En iyi uygulama koşulları ve sonuçlar belirlendikten sonra bitkilerle birlikte mümkün olan en düşük miktarlarda mordan maddeleri kullanılarak birbirinden tamamen farklı, özgün ve tekrar edilemeyen desenler elde edilerek giysi tasarımları yapılmıștır. Çalışmada; çevre dostu kumaş, mümkün olan en düşük mordan miktarları, yenilenebilir ve atık doğal boyar madde kaynakları, eko baskı gibi su ve enerji tüketiminin en az olduğu bir yöntem seçilerek ekolojik ve sürdürülebilir bir yaklaşım sergilenmiştir.

\subsection{Tekstil ve Moda Tasarımında Sürdürülebilirlik}

Sürdürülebilirlik kavramı, son yıllarda popüler hale gelmesine rağmen aslında çok daha uzun birikimlerin sonucu doğmuş ve bu kavram insanların çevreye ve doğaya verdiği zararlardan dolayı önem kazanmıștır. 20. Yüzyllda yaşanan sosyal ve ekonomik gelişmelerle birlikte ekosistem zarar görmüş ve beraberinde alternatif yaklaşımlara gitmek gerektiği anlaşılmıştır (Odabaşı, 2016, s. 8).

"Sürdürülebilirlik, insan geçim ve refahını etkileyen, hem küresel hem de yerel olarak ekolojik, ekonomik ve sosyopolitik boyutları kesişen, karmaşık çevresel dinamikleri içerir." (Ayvaz ve Can, 2017, s. 112).

Sürdürülebilirlik kavramı, Birleșmiş Milletler tarafından kurulan World Commision on Environment and Development (Dünya Çevre ve Kalkınma Komisyonu) tarafından komisyonun aldığı kararların toplandığı ve 1987 yılında yayınlanan Our Common Future isimli raporda ya da bilinen adıyla 1987 Brundtland Raporu'nda tanımlanmıştır. Bu tanıma göre sürdürülebilirlik; şu anki gereksinimleri, gelecek kuşakların kendi gereksinimlerini karşılama becerilerini tehlikeye atmaksızın karşılamaktır. (Odabaşı ve Şahin, 2018, s. 416)

Bu raporda sürdürülebilir kalkınmaya ișaret eden kriterler 3E (Ekolojik, Ekonomik ve Eșitlik/Etik) olarak belirtilmiştir (Odabaşı ve Şahin, 2018, s. 416). Bu üç niteliğin de sürdürülebilirliğin gerçekleşmesi için sağlanması gerekmektedir.

Ekolojik sürdürülebilirlik ile amaçlanan çevrenin ve doğanın gelecek nesiller için korunması, toksik olmayan ve çevreye zarar vermeyen dönüștürülebilir kaynakların kullanılmasıdır. Ekonomik anlamda sürdürülebilirlik ile sağlanmak istenenen, enerji, insan gücü ve hammadde gibi ekonomik kaynakların ihtiyaç fazlasının tüketiminin engellenmesidir. Kaynakların aşırı tüketimi bunun sağlanmasındaki en büyük engeldir. Sosyal/etik sürdürülebilirlik ise işçi hakları, insan hakları göz önünde bulundurularak bireyin temel ihtiyaçlarının karşılanmasıyla sağlanan sürdürülebilirliktir (Gürcüm ve Yüksel, 2011, s. 50).

Dünya üzerinde son yllarda daha sürdürülebilir bir yaşam oluşturmak için birçok alanda köklü değişikliklere ve bir dönüşüme zorunlu olduğumuz gerçeğiyle birçok tasarım teorisyeni, eğitimci ve tasarımcı da neler yapılabilir sorusuna farklı önermelerle yanıt bulmaya çalışmıștır. Bu önermelerden birisi de, üretim ve dolayısıyla tüketim alışkanlıklarımızı değiştirmeye, dönüştürmeye, yönelik yavaş tasarım manifestosudur (Türkmen, 2011, s. 60).

Sürdürülebilirlik moda ve tekstil endüstrisi için önemli bir kavramdır. Günümüzde Moda ve Tekstil endüstrisi çevreye en fazla zarar veren sektörlerdendir. Bu sebeple Sürdürülebilirlik kavramı son zamanlarda gündeme gelen bir konu olmuştur. Modada sürdürülebilir tasarım sadece ekonomik değil etik, sosyal, kültürel ve çevresel değerlerini de kapsamalıdır. "Moda sektöründe sürdürülebilirlik kavramının yerleşmesi için modacıların, imalatçların, piyasanın ve tüketicilerin davranışlarını değiştirmesi gerekmektedir. Yeşil moda, etik moda, sürdürülebilir moda, ekolojik moda günümüzde birbirlerinin yerine kullanılan kavramlardır" (Mangır, 2016, s. 148-149). 
Tekstil ve modada sürdürülebilir bir eğilim için üretim tüketim yapısının çevre ve insan sağlı̆̆ına zarar vermeyen ve duyarlı hale getirilmesi gerekmektedir.

Tekstil ve moda sektörü üretim ve tüketimin en hızlı geliştiği sektörlerden bir tanesidir. Sektörde giderek artan bu sorunun çözümü için, sürdürülebilir malzemelerin ve üretim yöntemlerinin kullanılması gerekmektedir (Ayvaz ve Can, 2017, s. 113). "Bunun için konvansiyonel doğrusal malzeme akıșı yerine döngüsel malzeme akışı benimsenmeli ve geri dönüştürülmüş liflerin kullanımına yönelinmelidir" (Akgümüş, Çay, Çelik ve Eser, 2016, s. 47).

“Tekstil sektöründe sürdürülebilirliğin sağlanabilmesi için tekstil ekolojisi kavramı önem arz etmektedir. Tekstilde ekoloji; üretim ekolojisi, insan ekolojisi ve atık ekolojisi olmak üzere üç grupta incelenebilir" (Ayvaz vd., 2017, s. 114).

“Tekstilde ekoloji yaklaşımına göre; üretimler ekolojik etik çerçevesinde yapılmalı, ürünler insan sağlı̆̆ açısından zararlı olmamalı ve ömrünü tamamlayıp atık haline gelen ürünler sürdürülebilirlik felsefesine uygun olarak değerlendirilmelidir" (Ayvaz vd., 2017, s. 114).

Hammaddenin çevre dostu koşullarda üretilmesi, kimyasalların çevreye zarar vermeyecek ürünlerden seçilmesi, solunum, sindirim ve ter yoluyla insana zarar vermeyecek giysilerin üretilmesi, üretim atıklarının ve kulanım sonucu oluşan atık giysilerin geri dönüşüm süreçlerinin gerçekleştirilmesi gibi konular, tekstilde ekoloji, sürdürülebilirlik açısından önemlidir. (Kurtoğlu ve ark., 2004; Ayvaz ve Can, 2017, s. 114)

Giderek büyüyen bir eğilimle birlikte etkili tasarımcılar yeni malzemeler, teknoloji, tasarımın psikolojik yönü ile evrensel sorunlara karşı bireysel çözümlerin 21. yüzyılda tasarım konusundaki yeni odak noktaları olduğunu açıklamışlardır (Türkmen, 2011, s. 60).

21. yüzyılın bilinçli tasarımcısının dürüst, hassas ve merhametli yönlerinin bulunması gerektiğinin savunulduğu manifestoda, tasarımcının tasarlayacağı ürünlerin, materyallerin, servislerin sürdürülebilir olması gerektiğine dikkat çekilerek eko-çoğulcu bir tasarım anlayışını benimsemekte olduğu ifade edilmektedir (Fuad-Luke'den aktaran, Odabașı ve Şahin, 2018, s. 419).

Eko baskı tasarımında su ve enerji kaynaklarının minimum kullanımıyla tasarruf sağlanmakta, doğal lifler kullanılmakta, toksik etki olmaksızın ve kimyasal boyarmaddeler kullanılmadan doğadaki bitkilerle yapılan desenlendirmelerle insan ve çevre sağlı̆̆ına zarar vermeden etik moda anlayışına ve sürdürülebilirliğe katkılar sağlanmaktadır. Bu bağlamda eko baskı tasarımının yenilenebilir kaynakları kullanarak ve daha az kaynak tüketimi ile gerçekleştirilebilen sürdürülebilir bir yaklaşım olduğu söylenebilir.

\subsection{Baskıda Farklı Bir Yaklaşım Olarak Bitkilerle Desenlendirme: Eko Baskı}

Eko boyama ve eko baskı terimleri, doğal boyamada herhangi bir ekstraksiyon işlemi yapılmadan bitkilerin doğrudan kullanımını tanımlamak için kullanılmaktadır. Eko boyama ve eko baskı yöntemleri arasındaki farklar, benzerlikler ve elde edilen sonuçlar iyi ayırt edilmelidir. Aslında iki yöntemde farklı etkiler elde edilmektedir. Eko boyamada kumaş üzerinde suluboya efektleri benzeri bir görünüm elde edilirken, eko baskıda ise; kumaş yüzeyine keskin, canlı, tatmin edici bir desen aktarımı gerçekleștirilmektedir.

Tüm doğal lifler ve insan yapısı liflerin çoğunluğu doğal boyalarla renklendirilebilmektedir. Endüstride ve sanatsal çalışmalarda uygulanan klasik baskı tekniklerinden oldukça farklı alternatif bir desenlendirme şekli olarak, bitkilerin/ağaçların çiçek, yaprak, dal ve tohum gibi kısımlarının doğrudan kullanılarak kumaş üzerinde desen oluşturulması tekniğine Eko Baskı (Eco Print) adı verilmektedir. Burada renklendirme ve desenlendirme doğal boyar maddelerin, bitkilerin etkisiyle yapılmaktadır. Bitki ve ağaçların çeşitli kısımları toplanabildiği gibi kendiliğinden dökülen yaprak, tohum gibi atık kısımların da değerlendirilebildiği sürdürülebilir bir tekniktir (İşmal, 2016, s. 84). Çevre dostu bir baskı tekniği olan eko baskıda sonuçlar bitkinin türüne bağlı olarak çok çeşitlidir. Bitkilerin yaprak ve çiçek kısımları sıklıkla kullanılmaktadır (Ikhsani \&Yulistiana, 2020, s. 58).

Eko boyama ve baskı, geleneksel doğal boyamaya farklı bir yaklaşım olarak ele alınabilir. Bu teknik, sanat ve bilimsel yöntemin kombinasyonunu gerektiren çok zengin bir uygulama alanıdır. Bu teknik tasarımcılar ve sanatçılara hayal güçlerini sınırsızca kullanma olanağı sağlamaktadır. Dolayısı ile öngörülemeyen sonuçların, desenlerin, renklerin ve görsel efektlerin elde edilebilmesi mümkündür.

Eko baskı tekniği boyasız kumașlara ve zemini doğal boyar madde ile boyanmış kumaşlara uygulanabilmekte ve bazı uygulama koşullarına bağlı olarak üç boyut etkisi de sağlanabilmektedir. 
Eko baskı ve boyama teknikleri bitkiler, meyveler, sebzeler, biyo atıklar ve yan ürünlerde bulunan boyar maddeleri kullanarak görsel etkilerin yaratıldı̆̆ı tekniklerdir. Bu teknikler sayesinde, bitkiler doğal şablon olarak kullanılarak kumaș yüzeyinde birbirinden ilginç ve șașırtıcı dokular, izler, șekiller, renk tonları elde edilebilmektedir. Eko baskı tekniği yaygın olarak kumaş üzerine uygulanmasının yanı sıra, deri, kağıt ve seramik üzerine de yapılabilmektedir. Eko baskıda bitkilerin yerleşimine, temas ettirme ve gerekli basınç kuvvetini uygulama yöntemine bağlı olarak farklı teknikler uygulanabilmektedir.

Vurma (hapa zome), sıcak yuvarlanmıș rulo halinde eko-baskı, soğuk rulo eko-baskı (soğuk paketlenmiș eko baskılar), pas boyama, güneşle boyama olmak üzere farklı şekillerde eko baskı uygulamaları yapılabilir (Flint, 2008; Arğun, Çolak ve Kaygusuz, 2020, s. 218).

Kumaş üzerinde istenen desene göre yapraklar ve çiçekler düzenlendikten sonra kumaşın sıkıca sarılıp, bağlanıp buharlanması, farklı bir yöntem olarak kumaşın yarısının üzerine istenen desene uygun olarak yapraklar ve çiçekler düzenlendikten sonra kumaşın katlanması ve renk çıkana kadar dövülmesi ya da söz konusu iki tekniğin kombinasyonu şeklinde uygulamalar da olabilmektedir (Nurcahyanti \& Septiana, 2018, s. 398).

Özel görünümlü tasarıma ek olarak; tekstil endüstrisindeki kimyasal atıklardan kaynaklanan çevresel ve ekosistemle ilgili zararları azaltmak için alternatif bir yöntem olarak Eko baskı tekniği kullanılabilir. Eko baskı alanındaki tasarım yenilikleri çok değişken olmakla birlikte, teknikler sürekli olarak geliştirilerek ürün kalitesini artırmaya devam edilebilmektedir (Heriningsih, Mardiana \& Warsiki, 2020, s. 34).

Bir bitkinin yapısı, rengi ve içerdiği su miktarı bitkinin eko baskıda kullanılmasını belirleyici faktörlerdendir (Heriningsih vd., 2020, s. 34). Her mevsimdeki bitkiler farklı pigmentlere sahip olmakla birlikte her birinden elde edilen farklı renklerin kumaş üzerine aktarılmasını sağlar. Bitkilerin taze, kuru haldeki yaprakları ve yeni düşen yaprakları farklı sonuçlar vermektedir. Gelişme olasılığı çok geniş olan eko baskı tekniğinde kullanılan doğal boyalar olarak sınıflandırılmayan çeşitli bitki türleri, doğal boyalar haline gelebilir (Alvin \& Wirawan, 2019, s. 1).

Bitki türü, mordan maddesi cinsi, mordanlama yöntemi, asidik ve bazik (alkali) maddeler ile farklı pH değerleri gibi sonuçları belirleyici etkenler üzerinde deneysel çalışmalar ve gözlemler yapılarak elde edilebilecek görsel etkiler hakkında öngörülerde bulunulabilir.

Ekolojik baskı tasarımında yaygın olarak, çınar yaprağı, okaliptüs yaprağı, çam ağacı yaprağı, gül yaprağı ve yalancı karabiber ağacı yaprakları kullanılmaktadır. Bunun yanı sıra çeşitli bitkiler ve çiçekler de kullanılmaktadır. Kök boya, nar kabuğu, soğan kabuğu, zerdeçal doğal boya uygulamalarında sıklıkla kullanılan kaynaklara bazı örneklerdir.

Biberiye, gül posası, lavanta, mate atıkları (Akar ve Bulut, 2012), portakal kabuğu (Hou vd., 2013), gül atıkları (Karaboyacı, 2014), lavanta posası, katır tırnağı çiçeği, kırmızı şarap (Karaboyacı ve Uğur, 2014), badem meyvesinin dış yeșil kabuğu (İșmal ve Yıldırım, 2012) ve zeytinyağı üretiminin önemli bir yan ürünü olan prina (İșmal, 2014) doğal boyamalarda başarılı bir şekilde kullanılmışlardır.

Doğal boyamada boya alımını ve fiksajını iyileştiren, elde edilen rengi ve haslık özelliklerini belirleyen metal tuzları, metal iyonları içeren doğal bileşikler veya diğer kompleks oluşturucu maddelere ihtiyaç duyulur. Bu maddelere mordan maddeleri denilir. Renk verimi ve koordinatları mordan cinsi ve mordanlama yöntemine önemli derecede bağlıdır. Her mordan farklı boyar madde kompleksi meydana getirerek tamamen farklı renkler ve haslık özellikleri elde edilmesini sağlar (İşmal, 2019, s. 43).

Eko baskıda da doğal boyamada olduğu gibi farklı renk cinslerinin/tonlarının elde edilebilmesi ve izlerin/desenlerin daha keskin, parlak ve canlı şekilde elde edilebilmesi için mordan maddelerinin kullanılması gerekmektedir.

Geleneksel mordan maddeleri olarak kullanılan bazı metal tuzları ekolojik açıdan doğal boyaların kullanımına getirilen en önemli eleştirilerdendir. Bu sebeple ekolojik zararlarının daha az olduğu bilinen şap, demir gibi bazı kimyasal mordanların ve alternatif olarak metal içeren çeşitli bitkilerin biyomordan olarak kullanılması tercih edilmektedir (İșmal, 2019, s. 47-48). Hangi mordan maddesi olursa olsun mümkün olan en düşük miktarlarda kullanılmasına özen gösterilmelidir.

Doğal boya uygulama yöntemini daha sürdürülebilir ve çevre dostu hale getirmek için yenilikçi bir yaklaşım olarak biyomordanlar kullanılmaktadır. Metal mordanlara bir alternatif olarak, bademin dış yeşil kabuk atıklarıyla yün liflerinin doğal boyamasında biyomordanların renk verimi ve haslık özellikleri üzerindeki etkileri incelenmiştir (İşmal, Özdoğan ve Yıldırım, 2014). 
Biyomordanlar metal iyonları, tanenler, tannik asit vb. içeren doğal malzemelerden çoğunlukla bitkisel kaynaklardan sağlanır ve doğal boyamada mordan görevi görürler. Sumak ve myrobolan gibi bazı bitkiler, zengin renklendirici madde, metal, tanen vb. içeriğine ek olarak hem renklendirici hem de mordan olarak işlev görebilir. Biyomordanlar yüksek tanen içeriğine sahip bitkilerdir (Prabhu \& Teli, 2011; İşmal, Özdoğan ve Yıldırım, 2015, s. 343).

Bitkilerden elde edilen klorofil ilk kez biyomordan olarak yünlü kumaşların boyanmasında kullanılarak başarılı sonuçlar elde edilmiştir (Guesmi, Hamadi, Ladhari, Msaddek \& Sakli, 2013). "Nar, akasya ve zerdeçal gibi bazı biyo materyaller, tekstil endüstrisinde mordan olarak kullanılma potansiyeline sahiptir" (Adeel, Amin, Salman, Usama \& Zahoor, 2020, s. 428). Özellikle son yıllarda doğal boyaların kullanımıyla ilgili yenilikçi yaklaşımlar, modern yöntem ve teknikler de söz konusudur.

Çevre dostu modern yöntemler olarak, doğal boyamada ses ötesi dalgalar (ultrason), mor ötesi ışınlar (UV), mikrodalga, gama ışınları kumaş yüzeyinin değişime uğratılması ve renk veriminin artırılması için kullanılmıştır (Adeel, Amin, Ahmad, Batool \& Hassan, 2020, s. 379).

Renk verimi, su ve enerji tüketimi, zaman, maliyet açısından modern yöntemlerin geleneksel yöntemlere göre üstünlükleri vardır (Adeel, Ghaffar, Mustaan, Rafi \& Salman, 2018, s. 56).

Modern yöntemlerden plazma işleminin yün kumaşların doğal boyaması ve antibakteriyel özellikleri üzerindeki etkileri (Ghoranneviss vd., 2011) ve plazma ile poliester kumaşların yüzeylerinde fonksiyonel grupların oluşturulması (Ghoranneviss, Shahidi \& Wiener, 2015) incelenmiştir.

Plazma işlemi yünlü kumaşların kök boya ve muhabbet çiçeği ile boyanarak UV ışınlarına karşı koruma özelliği (Moazzenchi \& Shahidi, 2019) ve pamuklu kumaşlara ise zerdeçal ile boyanarak antibakteriyel özellik kazandırmak için uygulanmıştır (Elahi, Ghoranneviss \& Shahidi, 2016).

Yeni bir doğal boya kaynağı olarak pamuk kozasının sulu özüyle yün liflerinin renklendirilmesi plazma yöntemi ve kitosan ile gerçekleştirilmiş (Haji, Mehrizi \& Sharifzadeh, 2016), plazma işlemiyle Arnebia euchroma bitkisi, pamuk kozasının kurumuş hali ve harmal tohumları doğal boya olarak kullanılarak yün liflerinin boyanmasındaki etkileri araștırılmıș (Haji, 2020a), yün liflerinin civanperçemi ve kına yaprakları ile doğal boyamasını optimize etmek için oksijen plazma ișlemi uygulanmıștır (Haji, 2020b).

Doğal boyamalarda çevre dostu bir yöntem olarak plazma teknolojisinin en çok kullanılan doğal ve sentetik liflerin yüzey modifikasyonu ve boyanmaları üzerindeki etkileriyle ilgili kapsamlı bir gözden geçirme çalışması yapılmıştır (Haji \& Naebe, 2020).

İpek lifinin tarçın kabuğu ile boyanmasında mikrodalga işlemiyle boya özütleme (ekstraksiyon) verimi artırılarak, kimyasal mordan ve biyomordanlar kullanılmıș, yeni renk tonları elde edilmesinin yanı sıra haslık değerleri de iyileştirilmiştir (Adeel vd., 2020).

Lyocell gibi rejenere selülozik esaslı yapay bir lif olan Modal liflerinden yapılmış kumaşın kurkumin ile doğal boyamasında farklı sıcaklıkların etkisi ve adsorpsiyon kinetiği incelenmiştir (Haque, Farzana, Hussain, Smriti \& Siddiqa, 2018).

Son yıllarda doğal boyama ve boyar madde kaynakları ile ilgili yapılan araştırmalarda daha sürdürülebilir, çevre dostu yöntemler ve geri dönüşüm açısından atık malzemelere olan ilgi artmıştır. Bu bağlamda atık malzemelerle ilgili çeşitli çalışmalar yapılmıştır.

Sürdürülebilirlik açısından atık ürünlerin çevresel etkileri en aza indirgenmelidir. Alternatif yeni doğal boya kaynakları olarak bademin dış yeşil kabukları (İşmal ve Yıldırım, 2012) ve zeytinyağı üretiminin bir yan ürünü olan prina (İșmal, 2014) kaynakçada ilk kez yün liflerinin boyanmasında farklı metal mordanlarla birlikte kullanılmıștır. Yünün prina ile boyanmasında ayrıca biyomordanların etkileri incelenmiș ve metal mordanlarla kıyaslamanın yanı sıra detaylı maliyet hesaplaması da yapılarak doğal boya ve sentetik boya kullanımında kimyasal madde, boya, su ve enerji tüketimleri karşılaştırılmıştır (İşmal, 2017).

Bitkisel bir atık olarak bakla kabuğu, poliamid/elastan kumaşın doğal boyanmasında farklı mordan maddeleri ile birlikte kullanılmış ve ayrıca metalik mordanlara alternatifler sağlamak amacıyla renk verimi ve yıkama haslıkları değerlendirilmiştir (İşmal ve Yıldırım, 2019a).

Doğal bir atık olan muz kabuğunun, metalik mordanlara alternatif olarak çeşitli mordanlarla birlikte kullanımı ile poliamid kumaş üzerindeki boyama etkisi incelenmiştir (İşmal ve Yıldırım, 2019b).

Doğal boyalarla yapılan desenlendirme çalıșmalarına bir örnek olarak, bademin dış yeşil kabuğu, prina, muz kabuğu, biberiye, bakla kabuğu, soğan kabuğu, ceviz kabuğu, enginar, nar kabuğu gibi organik atıklar ile çevre dostu metal tuzları ve biyomordanlar kullanılarak yün, pamuk, poliamid, pamuk/poliamid karışımı 
kumaşların renklendirilmesi ve desenlendirilmesi amacıyla çeşitli rezerve boyama teknikleri uygulanmıştır (İşmal, Sağduyu ve Yıldırım, 2019).

Pamuğun boyanması ve fonksiyonel bitim işlemi özelliği kazandırılması için Berberis vulgaris L. tarımsal atıkları ve sitrik asit kullanılarak en yüksek renk verimi elde edilmeye çalışılmış ve antibakteriyel testler yapılmıştır (Haji, Nasiriboroumand, \& Qavamnia, 2018).

Sürdürülebilirlik ve etik moda anlayışına katkı sağlayan eko baskı tasarımları ve doğal boyama uygulamaları giysi, aksesuar, ev tekstili gibi ürünlerin tasarımları ve üretimleri için uygulanagelmektedir. Mevcut durumda eko baskl, seri üretim şeklinde değil, küçük çaplı ve el emeğine dayalı, kişiye özel bir üretim niteliğindedir. Her tasarım kendine özgü ve tek olduğundan özel üretim olarak niş pazarda yerini almaktadır. Doğal boyar maddelerle yapılan uygulamalar ile ilgili olarak tüm dünyada bazı tekstil işletmelerinin seri üretime geçmeye yönelik ar-ge çalışmaları bulunmaktadır.

\subsection{Eko Baskı ile İlgili Yapılmış Olan Çalışmalara Bazı Örnekler}

Eko baskı tasarımında sürdürülebilir ürünler kavramıyla eko modanın geliştirilmesi, çevre dostu tekstil ürünlerine bir alternatif sağlamak ve estetik değerler katmak amacıyla çalışmalar yapılmıştır. Bu konuda çalışan çeşitli sanatçılar ve tasarımcılar vardır. Eko baskı tekniğinin öncü ismi Avusturalya doğumlu lif sanatçısı India Flint'tir. Elbise, kağıt, keçe, ekolojik sürdürülebilir boyalarla çalışmalar yapmakta, bu tekniği geliştiren sanatçı olarak kabul edilmektedir. Birçok üniversitede seminerler vermiş, eko baskı yapımı ile ilgili kurslar ve atölye çalışmaları düzenlemiştir. Dünyanın değişik yerlerinde birçok sergiler açmıştır. India Flint dışında Irit Dulman, Merina Lanari, Terria Kwong gibi eko baskı konusunda çalışan önemli tasarımcılar vardır.

Doğu Java Kediri'de batik ustası olan Hardini eko baskı tekniğini koyun derisi kullanarak geliştirmiştir. Bu çalışmada eko baskı için, koyun derisi üzerine, daun jarak yaprakları, lanang yaprakları, daun jati (tik) yaprakları, yabani bitkiler, çeşitli krizantem çiçeklerini kullanarak çanta ve cüzdan gibi aksesuar ürünleri yapmıştır (Mutmainah \& Wahyuni, 2020).

Sumatera Utara Üniversitesi tarafından düzenlenen sempozyumda bir seminer etkinliğinde oluşturulan çalışmada geri dönüştürülmüş kâğıt üzerine yapılmış eko-baskı kapaklı blok not defterler, deri cüzdan ve çanta için (tote-bag) kumaş materyal üzerine eko-baskı tekniği uygulanmıștır (Nuryawan, 2020). Kaine Art Fabric tarafından ev endüstrisindeki ürünlerde doğal kaynaklı boyalar ve eko baskı tekniği kullanılmıştır (Maharani, 2018).

Keten kumaşlarda üretim sürecinde doğru teknikler kullanılarak en uygun eko baskı tekniğinin uygulanması amaçlamıştır (Ramadhan \& Salsabila, 2018). İpek kumaşa uygulanan eko baskı tekniğinde tik yaprakları, doğal boyamada Endonezya'daki geleneksel tekstil üretiminde kullanılan Caesalpinia wood ve Terminalia jewelica kabuğunun doğal özleri kullanılmıştır (Dartono, Herlina \& Setyawan, 2018).

Okaliptüs yapraklarıyla ipek ve yün eşarp üzerine eko baskı tekniği uygulanarak deneysel bir araştırma yapılmıştır. Farklı mordanlar kullanılarak renk değişimi denenmiș, çalıșmanın sonuçlarına göre mevcut ürünlerden farklı eşarp tasarımı elde edilmiştir (Jeong \& Kang, 2017). İpek kumaş üzerine okaliptüs yaprakları, gül yaprakları, papatya bitkisi kullanılarak buharlama işlemiyle eko boyama yapılmıştır (Husna, 2016). Bu çalışmada bitkilerin net keskin kenarlı izleri yerine suluboya efektleri elde edildiği görülmektedir.

İpek kumaș üzerine doğal boyalar ve atık demirler hem mordan, hem boyar madde şeklinde kullanılarak eko baskı tekniği uygulanmıştır. Doğal boya kaynakları olarak jambal (Peltophorum pterocarpum), secang (Caesalpia sappan L.), tegeran (Macluracochinchinensis) ve mango yaprakları (Mangifera indica) kullanılmıştır. Eko baskıda sulu boya efektleri gözlemlenmiştir (Nissa, Pressinawangi \& Widiawati, 2014).

Türkiye'de de bu konuda bazı tezler ve makale çalıșmaları yapılmıștır. Yapılan bir yüksek lisans çalışmasında ipek kumaşa eko baskı tekniğiyle üç pano deseni tasarlanarak uygulanmıştır (Çermikli, 2019). Sanatta yeterlilik tezinde ise pamuk ve ipek kumaş üzerine eko boyama ve eko baskı tekniği uygulanmıştır (Can, 2016).

Eko baskı uygulanmış pamuklu ve ipekli kumaşların dayanıklılık düzeylerini belirlemek için yıkama, sürtünme ve ışık haslığı analizleri uygulanmıştır. Uygulanan baskılarda haslık değerlerinin iyi olduğu tespit edilmiştir (Akpınarlı ve Tambaş, 2019). Eko baskı tekniği ipek kumaşta yapılmış, sonrasında baskılı kumaşların renk ölçümleri yapılmış, yıkama haslı̆̆ı, sürtme haslığı, mukavemet ve uzama özellikleri test edilmiştir (Aydoğan, Atak, Bilge ve Erdem, 2018).

Ekolojik baskı tekniği mazı yaprakları, gül yaprakları, lavanta çiçekleri, çınar yaprakları, ceviz yaprakları, krizantem çiçekleri, ebegümeci, Amerikan sarmaşı̆̆ı yaprakları, gerbera çiçekleri, süs erik yaprakları, bulut 
ağacı yaprakları gibi çeșitli bitki ve çiçekler kullanılarak farklı tabaklanmıș deri örnekleri üzerine uygulanmış, farklı desen efektleri ve renk tonları elde edilmiștir (Arğun, Çolak ve Kaygusuz, 2020).

Doğal boyama ve eko baskıyla ilgili araştırmalar kapsamındaki bir çalışmada eko boyama ve eko baskının tasarımdaki önemi belirtilmiş, gül, çiğdem ve karanfil çiçekleri kullanılarak doğal boya esaslı bir uygulama yapılmıștır (Bilir, 2018).

\section{Deneysel Çalıșmalar}

Çalışmada doğal boya kaynakları olarak prina, zerdeçal, soğan kabuğu, kök boya, nar kabuğu toz olarak doğrudan ve özütleme (ekstraksiyon) yolu ile, mordan maddeleri olarak şap, demir II sülfat, bakır II sülfat ile birlikte Tencel $^{T M}$ Lyocell kumaşların ön ve aynı anda mordanlama yöntemlerine göre boyanmasında kullanılmıştır. Bu laboratuvar çalışması sonucunda bir renk paleti elde edilmiştir.

Daha sonra renk paletinden seçilen renklerde büyük parça kumaşlar; boyanmış ve üzerlerine çeşitli bitkilerle eko baskı uygulamaları yapılmıştır. Yapılan eko baskı ön denemelerinde farklı bitkilerin yaprakları ve çiçekleri kullanılarak kumaş üzerindeki desen, renk ve iz etkileri gözlemlenerek uygulama reçeteleri belirlenmiştir. Tasarımlarda kullanılacak giysilerin kalıplarına göre kesilmiş kumaşların bazılarının zemini boyasız bırakılmış bazıları ise doğal boya reçeteleriyle boyanıp, çeşitli bitkilerle eko baskı tekniği uygulandıktan sonra dikimleri yapılmıștır.

\subsection{Materyal ve Yöntem}

\subsubsection{Kumaș}

Çalışmada 165 g/m² ağırlığında dimi dokuma \%100 Tencel $^{T M}$ Lyocell kumaş kullanılmıștır.

\subsubsection{Bitkiler ve biyo atıklar}

Doğal boyamada; soğan kabuğu, kök boya, nar kabuğu, zerdeçal, zeytinyağı üretiminin bir yan ürünü olan prina, eko baskıda; okaliptüs yaprağı ve tohumları, gül yaprakları, çam ağacı yaprağı, çınar yaprağı, mimoza çiçeği, incir ağacı yaprağı, yalancı karabiber ağacı yaprakları ve tohumları kullanılmıştır.

\subsubsection{Mordanlar}

Boyamalarda şap (potasyum alüminyum sülfat), demir II sülfat ve bakır II sülfat mordanları Tablo 1'de gösterilen miktarlarda kullanılmıştır. Tasarımlar için doğal boyamalarda mordanlar tek başına ve karışımlar olarak çeşitli oranlarda uygulanmıştır.

\subsubsection{Mordanlama yöntemleri}

Tasarımlar için kumaşlara yapılan doğal boyama uygulamalarında ön ve aynı anda mordanlama işlemi yapılmıștır. Soğan kabuğu, zerdeçal ve prina ile ön mordanlama, kök boya ve nar kabuğu ile aynı anda mordanlama yöntemine göre boyamalar yapılmıştır.

\subsubsection{Cihaz ve malzemeler}

Hassas terazi, elektrik ocağı, geniş çelik tencere, plastik, tahta ve metal boru, alüminyum folyo, pamuk ipliği, çeşitli hacimlerde cam beherler ve mezürler, kum banyosu, cam karıştırma çubukları, naylon torbalar kullanılmıştır.

\subsubsection{Yöntem}

\subsubsection{Doğal boya kaynağının kullanım șekli}

Tüm doğal boya kaynakları çelik bıçaklı elektrikli öğütücü ile toz haline getirilmiştir. Kök boya ve nar kabuğu $6.6 \mathrm{~g} / \mathrm{L}$ konsantrasyonda doğrudan, soğan kabuğu, prina ve zerdeçal ise özütleme yapıldıktan sonra kullanılmıștır. Özütleme için $6.6 \mathrm{~g} / \mathrm{L}$ soğan kabuğu, $20 \mathrm{~g} / \mathrm{L}$ zerdeçal, $80 \mathrm{~g} / \mathrm{L}$ prina tozu kullanılarak $100^{\circ} \mathrm{C}$ de 1 saat kaynatılmıș ve süzülmüștür. Özütlemeden sonra eksilen hacimler 1 L'ye tamamlanarak boya banyoları olarak kullanılmıștır.

\subsubsection{Doğal boyama}

Boyamalar ön ve aynı anda mordanlama yöntemlerine göre $3 \mathrm{~g}$ kumaş ile 1/50 banyo oranına göre yapılmıştır. Sırasıyla $20 \mathrm{~g} / \mathrm{L}$ zerdeçal, $80 \mathrm{~g} / \mathrm{L}$ prina, 6,6 g/L soğan kabuğu boya banyoları ile $100^{\circ} \mathrm{C}$ 'de 1 saat $1 \mathrm{~g} / \mathrm{L}$ şap, 5g/L şap, 1g/L bakır II sülfat ve $1 \mathrm{~g} / \mathrm{L}$ mordanları ile ön mordanlama yöntemine göre boyamalar 
yapılmıştır. Ayrıca, 6,6 g/L kök boya ve 6,6 g/L nar kabuğu $1 \mathrm{~g} / \mathrm{L}$ şap ile $100{ }^{\circ} \mathrm{C}$ de 1 saat kaynatarak aynı anda mordanlama yöntemine göre boyamalar yapılmıştır.

Boyanan kumaș numuneleri daha sonra su ile yıkanmış ve oda sıcaklığında kurutulmuştur. Yapılan boyamalar Tablo 1' de görülmektedir.

Tablo 1. Doğal Boyama Reçeteleri

\begin{tabular}{|c|c|c|c|c|}
\hline Deneme & $\begin{array}{c}\text { Boyar maddenin } \\
\text { kullanım șekli }\end{array}$ & Mordan & $\begin{array}{c}\text { Mordanlama } \\
\text { yöntemi }\end{array}$ & Elde edilen renk \\
\hline $\begin{array}{l}1 \\
\text { Soğan kabuğu }\end{array}$ & $\begin{array}{l}\text { Özütleyerek } \\
\text { kullanım }\end{array}$ & $1 \mathrm{~g} / \mathrm{L}$ Bakır II sülfat & Ön mordanlama & \\
\hline $\begin{array}{l}2 \\
\text { Kök boya }\end{array}$ & $\begin{array}{l}\text { Toz halde } \\
\text { doğrudan } \\
\text { kullanım }\end{array}$ & 1 g/L Şap & $\begin{array}{l}\text { Aynı anda } \\
\text { mordanlama }\end{array}$ & \\
\hline $\begin{array}{l}3 \\
\text { Zerdeçal }\end{array}$ & $\begin{array}{l}\text { Özütleyerek } \\
\text { kullanım }\end{array}$ & 1g/L Şap & Ön mordanlama & \\
\hline $\begin{array}{l}4 \\
\text { Prina }\end{array}$ & $\begin{array}{l}\text { Özütleyerek } \\
\text { kullanım }\end{array}$ & 5g/L Şap & Ön mordanlama & \\
\hline $\begin{array}{l}5 \\
\text { Nar kabuğu }\end{array}$ & $\begin{array}{l}\text { Toz halde } \\
\text { doğrudan } \\
\text { kullanım }\end{array}$ & 1g/L Şap & $\begin{array}{l}\text { Aynı anda } \\
\text { mordanlama }\end{array}$ & \\
\hline $\begin{array}{l}6 \\
\text { Soğan kabuğu }\end{array}$ & $\begin{array}{l}\text { Özütleyerek } \\
\text { kullanım }\end{array}$ & 1g/L Şap & Ön mordanlama & \\
\hline
\end{tabular}


Tablo 2. Eko baskı tasarım işlem süreçleri.

\begin{tabular}{|c|c|c|c|c|c|c|c|}
\hline $\begin{array}{l}\text { Eko baskı } \\
\text { tasarımları }\end{array}$ & \begin{tabular}{|l} 
Doğal \\
boyama \\
yapılmış \\
kumaş
\end{tabular} & Mordan & $\begin{array}{l}\text { Mordanlama } \\
\text { yöntemi }\end{array}$ & $\begin{array}{l}\text { Eko baskıda } \\
\text { kullanılan } \\
\text { bitkiler }\end{array}$ & $\begin{array}{l}\text { Sarma ve } \\
\text { paketleme } \\
\text { biçimi }\end{array}$ & Fiksaj & Art işlemler \\
\hline $\begin{array}{l}\text { Tasarım } 1 \\
\text { Prina ile } \\
\text { boyanmış } \\
\text { kumaş } \\
\text { üzerine eko } \\
\text { baskı }\end{array}$ & \begin{tabular}{|l|} 
Deneme 4 \\
reçetesiyle \\
boyanmış \\
kumaş \\
üzerine
\end{tabular} & $\begin{array}{l}\text { 0,75 g/L } \\
\text { demir II } \\
\text { sülfat }\end{array}$ & $\begin{array}{l}\text { Ön } \\
\text { mordanlama }\end{array}$ & $\begin{array}{l}\text { Çınar yaprağı, } \\
\text { İncir ağacı } \\
\text { Yaprağı, } \\
\text { Mimoza çiçeği }\end{array}$ & $\begin{array}{l}\text { Demir } \\
\text { boruya } \\
\text { alüminyum } \\
\text { folyo ile } \\
\text { silindir } \\
\text { şeklinde } \\
\text { sarma }\end{array}$ & $\begin{array}{l}1 \text { saat } \\
\text { kaynar su } \\
\text { üzerinde } \\
\text { buharlama }\end{array}$ & $\begin{array}{l}\text { Demir çubuğa } \\
\text { sarılı kumaş } \\
\text { soğuduktan } \\
\text { sonra açllır, } \\
\text { ylkama } \\
\text { işleminden } \\
\text { sonra } \\
\text { kurumaya } \\
\text { bırakılır. }\end{array}$ \\
\hline $\begin{array}{l}\text { Tasarım } 2 \\
\text { Prina ve } \\
\text { zerdeçal ile } \\
\text { boyanmış } \\
\text { kumaş } \\
\text { üzerine eko } \\
\text { baskı }\end{array}$ & \begin{tabular}{|l} 
Deneme 3 \\
ve 4 \\
reçetesiyle \\
boyanmiş \\
kumaş \\
üzerine
\end{tabular} & $\begin{array}{l}\begin{array}{l}1,25 \mathrm{~g} / \mathrm{L} \\
\text { demir II } \\
\text { sülfat }\end{array} \\
0,25 \mathrm{~g} / \mathrm{L} \\
\text { şap }\end{array}$ & $\begin{array}{l}\text { Ön } \\
\text { mordanlama }\end{array}$ & $\begin{array}{l}\text { Çınar yapră̆ı, } \\
\text { gül yaprağı, } \\
\text { çam, mimoza } \\
\text { çiçeği, yalancı } \\
\text { karabiber } \\
\text { ağacı } \\
\text { yaprakları }\end{array}$ & $\begin{array}{l}\text { Demir } \\
\text { boruya } \\
\text { alüminyum } \\
\text { folyo ile } \\
\text { silindir } \\
\text { şeklinde } \\
\text { sarma }\end{array}$ & $\begin{array}{l}1 \text { saat } \\
\text { kaynar su } \\
\text { üzerinde } \\
\text { buharlama }\end{array}$ & $\begin{array}{l}\text { Demir çubuğa } \\
\text { sarılı kumaş } \\
\text { soğuduktan } \\
\text { sonra açılır, } \\
\text { ylkama } \\
\text { işleminden } \\
\text { sonra } \\
\text { kurumaya } \\
\text { bırakılır. }\end{array}$ \\
\hline $\begin{array}{l}\text { Tasarım } 3 \\
\text { Zerdeçal ile } \\
\text { boyanmış } \\
\text { kumaş } \\
\text { üzerine eko } \\
\text { baskı }\end{array}$ & \begin{tabular}{|l|} 
Deneme 3 \\
reçetesiyle \\
boyanmış \\
kumaş \\
üzerine
\end{tabular} & $\begin{array}{l}\text { 0,75 g/L } \\
\text { demir II } \\
\text { sülfat }\end{array}$ & $\begin{array}{l}\text { Ön } \\
\text { mordanlama }\end{array}$ & $\begin{array}{l}\text { Çınar yaprağı, } \\
\text { çam }\end{array}$ & $\begin{array}{l}\text { Demir } \\
\text { boruya } \\
\text { alüminyum } \\
\text { folyo ile } \\
\text { silindir } \\
\text { şeklinde } \\
\text { sarma }\end{array}$ & $\begin{array}{l}1 \text { saat } \\
\text { kaynar su } \\
\text { üzerinde } \\
\text { buharlama }\end{array}$ & $\begin{array}{l}\text { Demir çubuğa } \\
\text { sarılı kumaş } \\
\text { soğuduktan } \\
\text { sonra açlır, } \\
\text { yıkama } \\
\text { işleminden } \\
\text { sonra } \\
\text { kurumaya } \\
\text { bırakılır. }\end{array}$ \\
\hline $\begin{array}{l}\text { Tasarım } 4 \\
\text { Soğan kabuğu } \\
\text { ile boyanmış } \\
\text { kumaş } \\
\text { üzerine eko } \\
\text { baskı }\end{array}$ & \begin{tabular}{|l} 
Deneme 1 \\
reçetesiyle \\
boyanmış \\
kumaş \\
üzerine
\end{tabular} & $\begin{array}{l}\text { 8,3 g/L } \\
\text { demir II } \\
\text { sülfat }\end{array}$ & $\begin{array}{l}\text { Ön } \\
\text { mordanlama }\end{array}$ & $\begin{array}{l}\text { Okaliptüs } \\
\text { yaprağı, } \\
\text { yalancı } \\
\text { karabiber } \\
\text { ağacı } \\
\text { yaprakları }\end{array}$ & $\begin{array}{l}\text { Demir } \\
\text { boruya } \\
\text { alüminyum } \\
\text { folyo ile } \\
\text { silindir } \\
\text { șeklinde } \\
\text { sarma }\end{array}$ & $\begin{array}{l}1 \text { saat } \\
\text { kaynar su } \\
\text { üzerinde } \\
\text { buharlama }\end{array}$ & $\begin{array}{l}\text { Demir çubuğa } \\
\text { sarılı kumaş } \\
\text { soğuduktan } \\
\text { sonra açılır, } \\
\text { ylkama } \\
\text { işleminden } \\
\text { sonra } \\
\text { kurumaya } \\
\text { bırakılır. }\end{array}$ \\
\hline $\begin{array}{l}\text { Tasarım } 5 \\
\text { Kök boya ile } \\
\text { boyanmış } \\
\text { kumaş } \\
\text { üzerine eko } \\
\text { baskı }\end{array}$ & \begin{tabular}{|l|} 
Deneme 2 \\
reçetesiyle \\
boyanmış \\
kumaş \\
üzerine
\end{tabular} & $\begin{array}{l}0,5 \mathrm{~g} / \mathrm{L} \\
\text { demir II } \\
\text { sülfat } \\
0,25 \mathrm{~g} / \mathrm{L} \\
\text { şap }\end{array}$ & $\begin{array}{l}\text { Ön } \\
\text { mordanlama }\end{array}$ & $\begin{array}{l}\text { Okaliptüs } \\
\text { yaprağı, çam, } \\
\text { okaliptüs } \\
\text { ağacı } \\
\text { tohumları }\end{array}$ & $\begin{array}{l}\text { Demir } \\
\text { boruya } \\
\text { alüminyum } \\
\text { folyo ile } \\
\text { silindir } \\
\text { şeklinde } \\
\text { sarma }\end{array}$ & $\begin{array}{l}1 \text { saat } \\
\text { kaynar su } \\
\text { üzerinde } \\
\text { buharlama }\end{array}$ & $\begin{array}{l}\text { Demir çubuğa } \\
\text { sarılı kumaş } \\
\text { soğuduktan } \\
\text { sonra açllır, } \\
\text { yıkama } \\
\text { işleminden } \\
\text { sonra } \\
\text { kurumaya } \\
\text { bırakılır. }\end{array}$ \\
\hline $\begin{array}{l}\text { Tasarım } 6 \\
\text { Nar kabuğu ile } \\
\text { boyanmış } \\
\text { kumaş } \\
\text { üzerine eko } \\
\text { baskı }\end{array}$ & \begin{tabular}{|l|} 
Deneme 5 \\
reçetesiyle \\
boyanmış \\
kumaş \\
üzerine
\end{tabular} & \begin{tabular}{|l}
$2,5 \mathrm{~g} / \mathrm{L}$ \\
şap \\
$2,5 \mathrm{~g} / \mathrm{L}$ \\
kalay \\
klorür
\end{tabular} & $\begin{array}{l}\text { Ön } \\
\text { mordanlama }\end{array}$ & $\begin{array}{l}\text { Yalancı } \\
\text { karabiber } \\
\text { ağacı } \\
\text { yaprakları }\end{array}$ & \begin{tabular}{|l} 
Demir \\
boruya \\
alüminyum \\
folyo ile \\
silindir \\
şeklinde \\
sarma
\end{tabular} & $\begin{array}{l}1 \text { saat } \\
\text { kaynar su } \\
\text { üzerinde } \\
\text { buharlama }\end{array}$ & $\begin{array}{l}\text { Demir çubuğa } \\
\text { sarılı kumaş } \\
\text { soğuduktan } \\
\text { sonra açllır, } \\
\text { yıkama } \\
\text { işleminden } \\
\text { sonra } \\
\text { kurumaya } \\
\text { bırakılır. }\end{array}$ \\
\hline
\end{tabular}




\subsubsection{Yıkama haslığı testi}

Kumaşların yıkama haslık değerleri ISO Test yöntemine göre (ISO105 C06 - $40{ }^{\circ} \mathrm{C}$ 'de 30 dakika) yapılarak 4-5 olarak belirlenmiştir.

\subsubsection{Eko baskı uygulaması}

Eko baskı tasarımlarında farklı ölçülerdeki zemini boyalı ve boyasız kumaşlar Tablo 2' de gösterilen şekilde öncelikle mordan çözeltileri içinde $1 \mathrm{dk}$. bekletildikten sonra, kumaş sıkılarak düz bir zemine serilmiş, seçilen bitkiler belirlenen tasarıma uygun olarak yüzeye yerleştirilmiş ve üzeri kumaş ölçüsünde folyoyla kaplanarak demir boruya pamuk ipliğiyle sıkıca sarılarak bağlanmıştır. 1 saat buharlandıktan sonra açılarak yıkanıp kurutulmuş, daha sonra dikim işlemi uygulanmıştır.

\subsubsection{Tasarım süreci ve uygulamalar}

Tasarımlarda kullanılan giysi modellerinin bol ve deseni gösterecek şekilde olmasına dikkat edilmiştir. Giysilerde farklı model ve ölçüler kullanılmış, doğal boyama ve eko baskı tekniği uygulanarak renklendirmenin yanı sıra çeşitli bitkilerin izleri de net bir şekilde kumaş yüzeyinde elde edilerek desenlendirme yoluyla özgün tasarımlar yapılmıştır.

\subsubsection{Tasarımlar}

Tasarım 1: Bu tasarımda Tablo 1'deki Deneme 4 reçetesine göre elbisenin bütün parçalarına ait olan $579 \mathrm{~g}$ kumaş prina ile bej renginde boyanmıştır. Daha sonra, tasarıma uygun olarak çıkarılan kalıptaki, desenlendirme yapılacak olan kısımda; Tablo 2' deki tasarım 1'de belirtilen şekilde eko baskı işlemi gerçekleştirilmiştir. Elbise tasarımının uygulama sonucu ve detayları Şekil 1, Şekil 2 a-b'de görülmektedir.

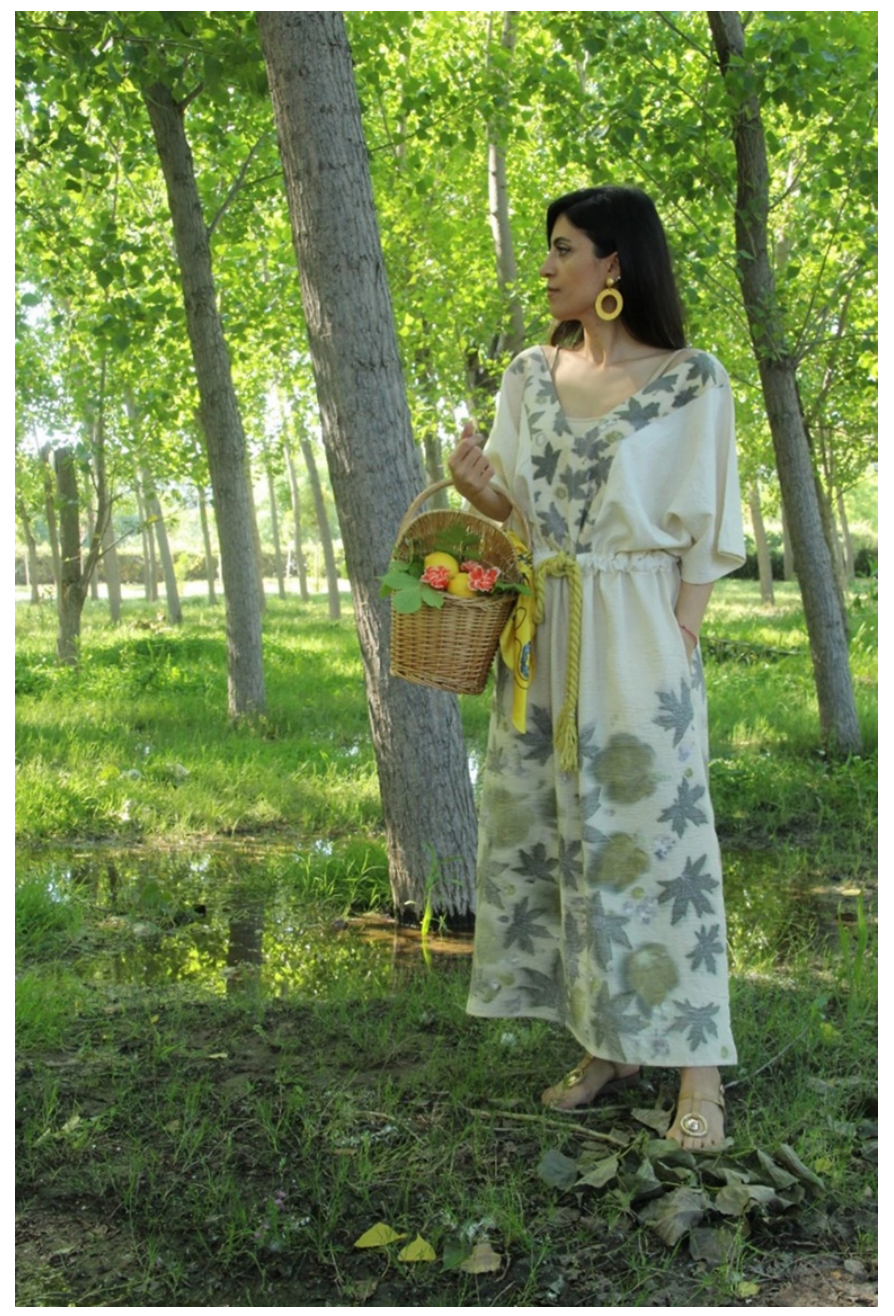

Şekil 1. Tasarım 1, elbisenin ön görünümü, Özge Özen, 2019. 


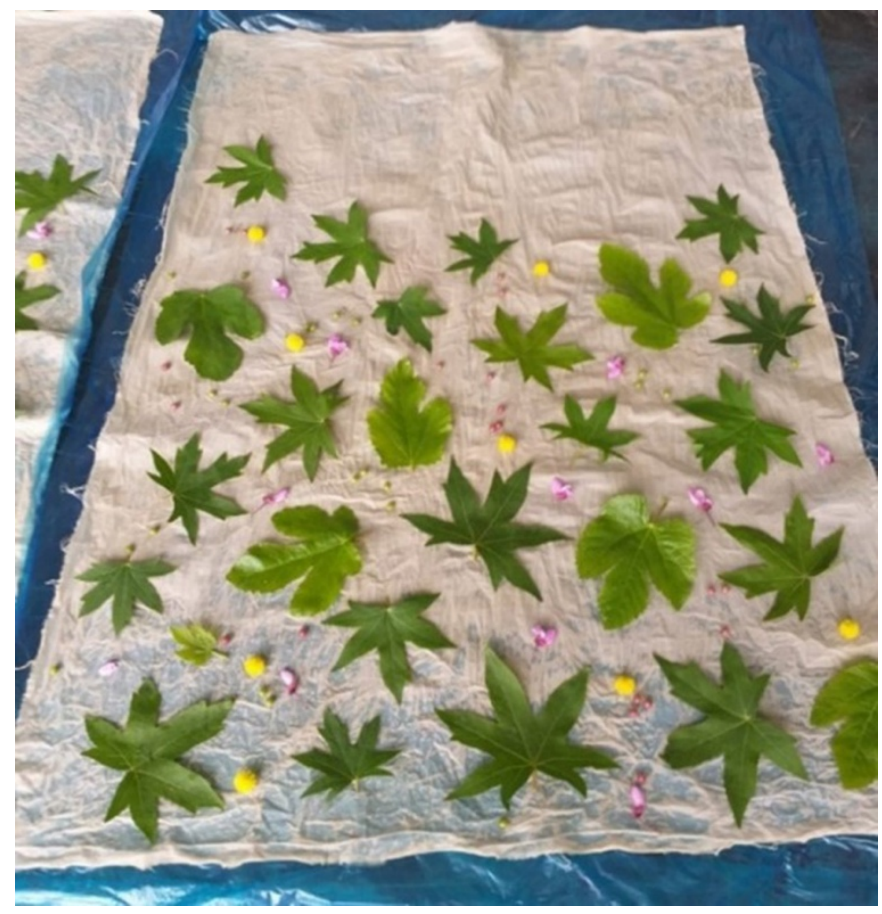

Şekil 2. a) Tasarım 1, zemini boyalı kumaş üzerine belirlenen düzene göre bitkilerin yerleșimi, Özge Özen, 2019.

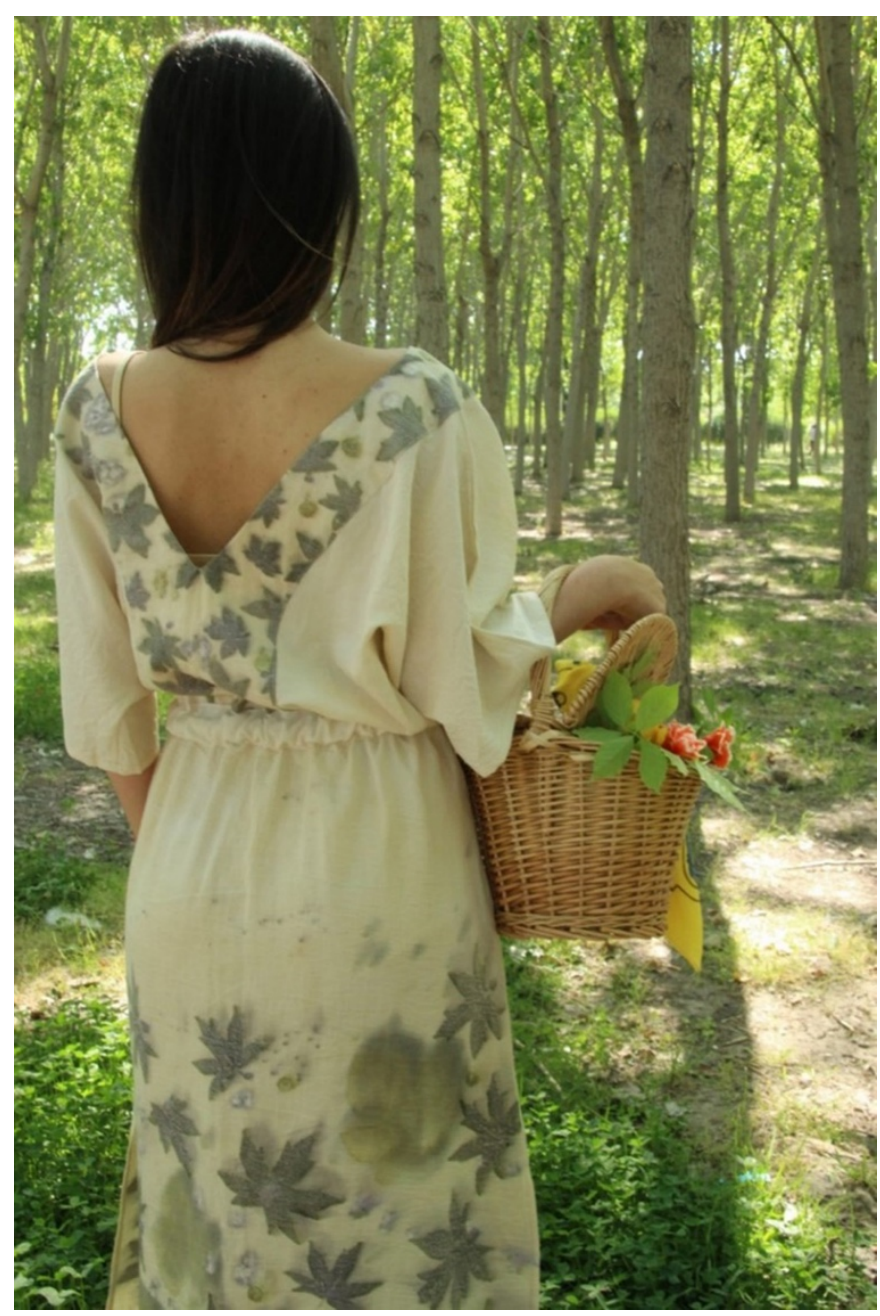

Şekil 2. b) Tasarım 1, elbisenin arka görünümü, Özge Özen, 2019. 
Tasarım 2: Bu tasarımda Tablo 1'deki Deneme 4 reçetesiyle eko baskı işlemi uygulanacak ceketin belirli kısımlarına ait olan 245 g kumaş prina ile bej renginde boyanmıştır. Eko baskı işlemi Tablo 2'de Tasarım 2'de belirtildiği şekilde yapılmıștır.

Ceketin sadece doğal boyama olacak kısımları Deneme 3 reçetesine göre zerdeçal ile boyanarak sarı bir renk elde edilmiştir. Ceket tasarımının uygulama sonucu ve detayları görülmektedir (Şekil 3a-b ve Şekil 4a-b).

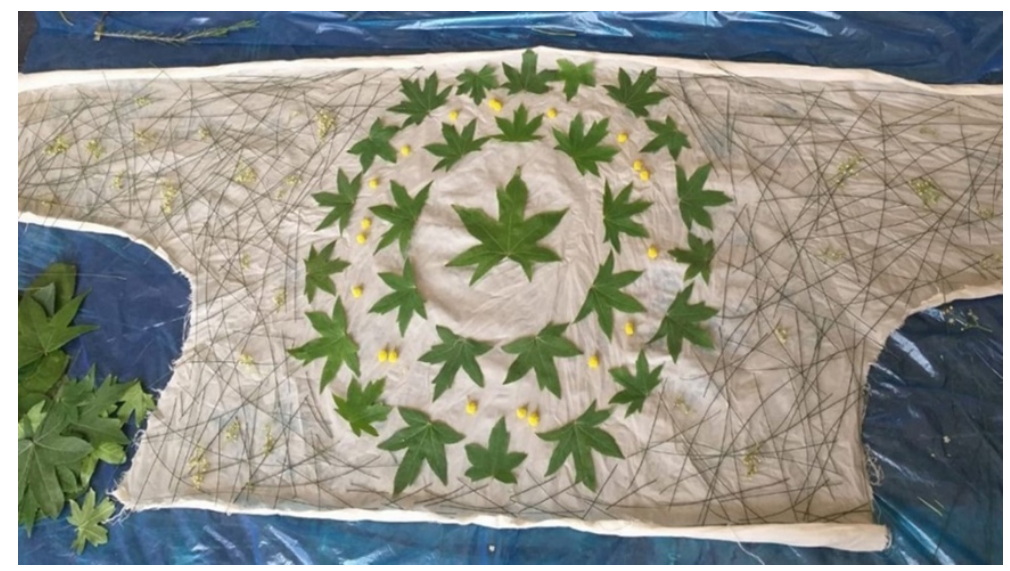

Şekil 3. a) Tasarım 2, ceket arka kısım, kumaş üzerine belirlenen tasarıma göre bitkilerin yerleşimi, Özge Özen, 2019.

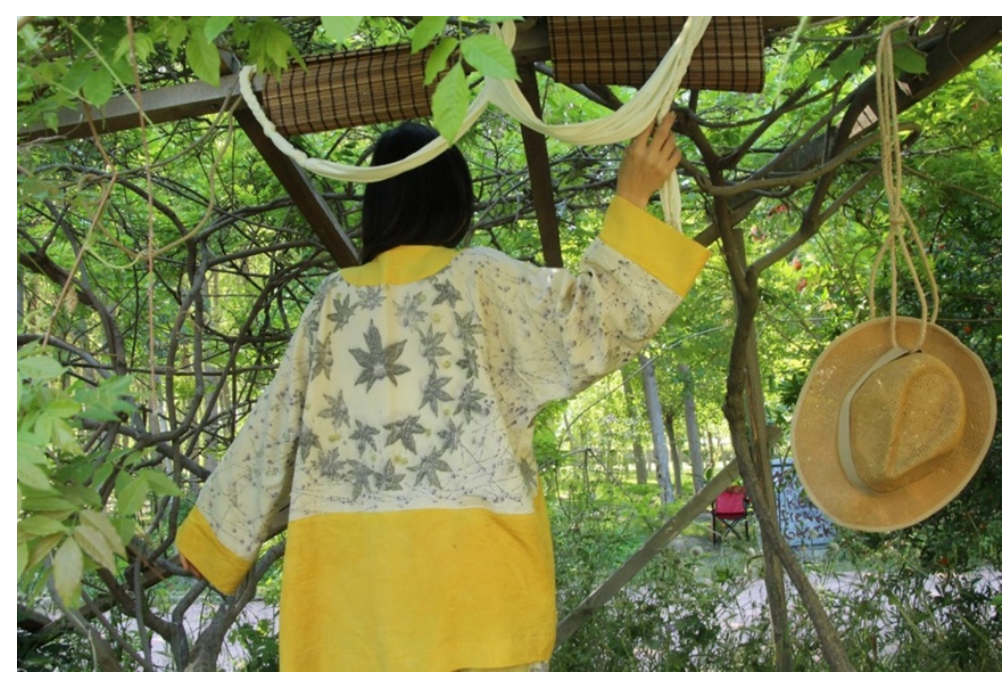

Şekil 3. b) Tasarım 2, ceketin arka detay görünümü, Özge Özen, 2019.

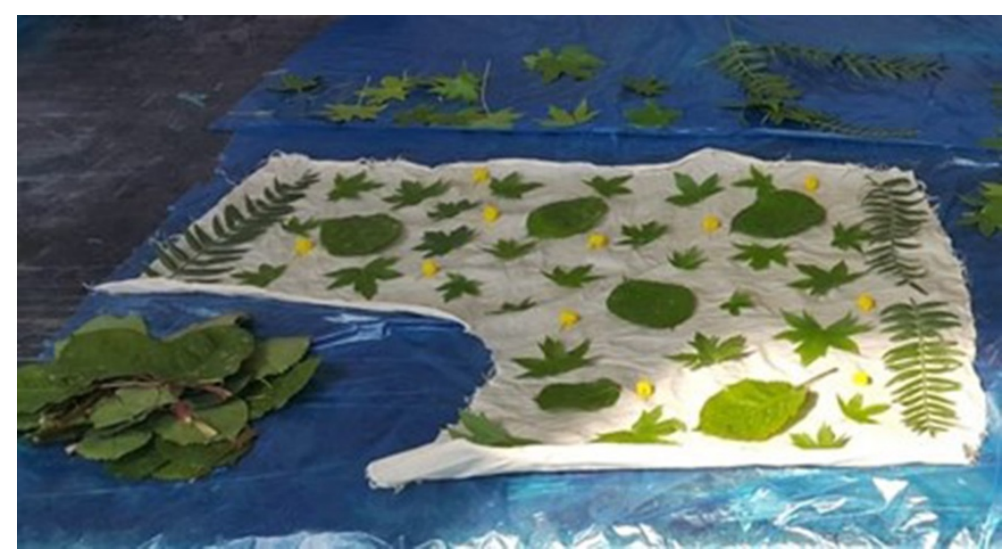

Şekil 4. a) Tasarım 2, ceket sol ön kısım, belirlenen tasarıma göre bitkilerin yerleșimi, Özge Özen, 2019. 


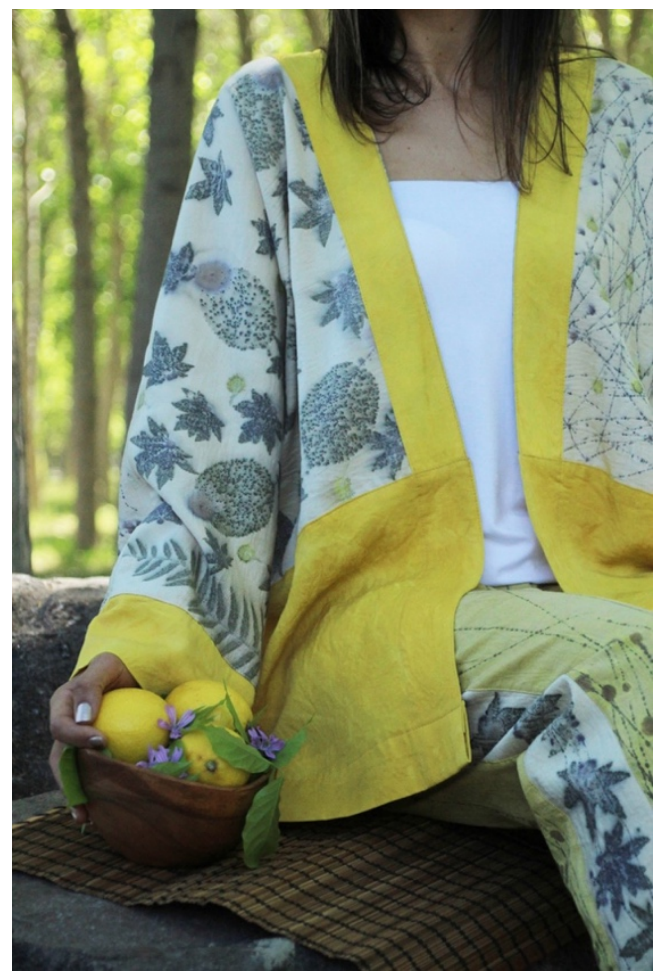

Şekil 4. b) Tasarım 2, ceketin detay görünümü, Özge Özen, 2019.

Tasarım 3: Bu tasarımda Tablo 1'deki Deneme 3 reçetesine göre pantolona ait $262 \mathrm{~g}$ kumaş zerdeçal ile sarı renkte boyanmıștır. Eko baskı ișlemi Tablo 2'de Tasarım 3'te belirtilen șekilde yapılmıștır. Pantolon tasarımının uygulama sonucu Şekil 5 ve Şekil 6' da görülmektedir.

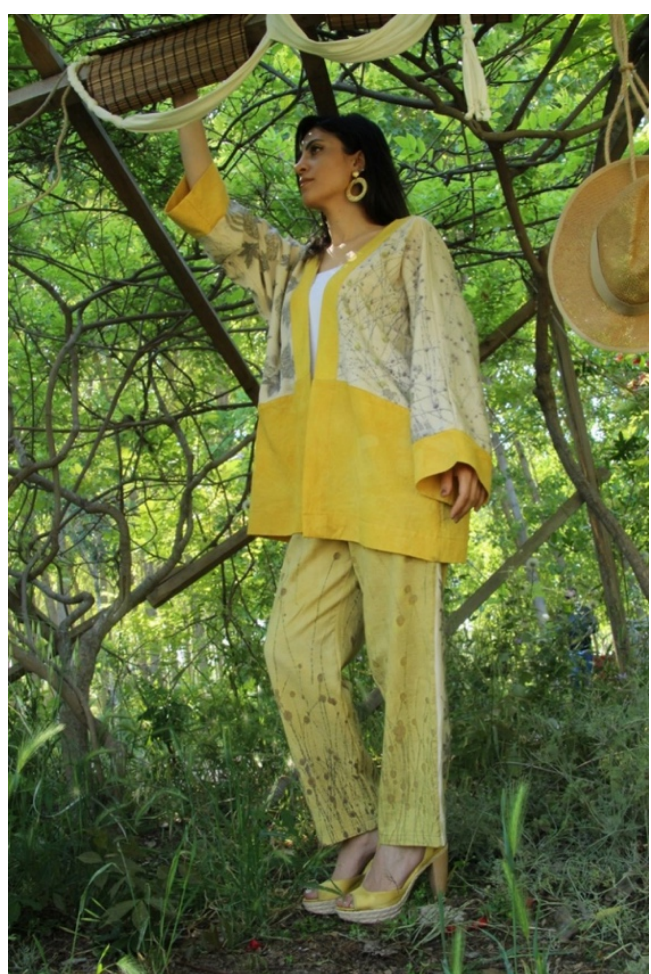

Şekil 5. Tasarım 3, pantolon tasarımının ön görünümü, Özge Özen, 2019. 


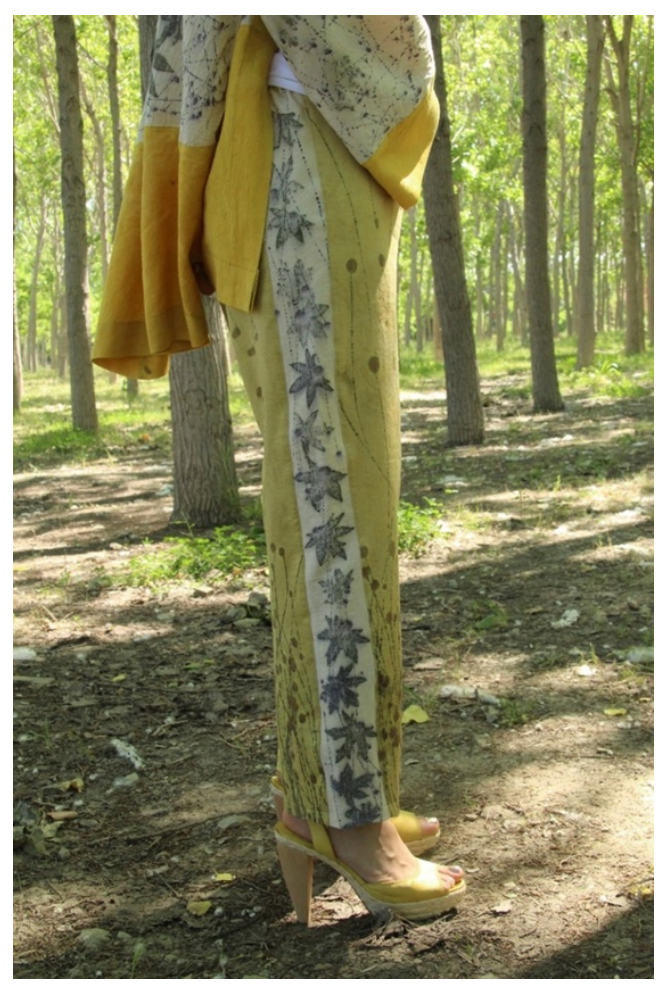

Şekil 6. Tasarım 3, pantolon tasarımının yandan görünümü, Özge Özen, 2019.

Tasarım 4: Bu tasarımda Tablo 1' deki Deneme 1 reçetesine göre tuluma ait 187 g kumaş soğan kabuğu ile sütlü kahve renkte boyanmıştır. Tulumun diğer bir kısmına ait 45 g kumaş Tablo 1'deki Deneme 6 reçetesine göre turuncu renkte boyanmiştır.

Eko baskı işlemi; Tablo 2' deki Tasarım 4' de belirtilen şekilde yapılmıştır. Tulum tasarımının uygulama sonucu ve detayları Şekil 7a-b ve Şekil 8' de görülmektedir.

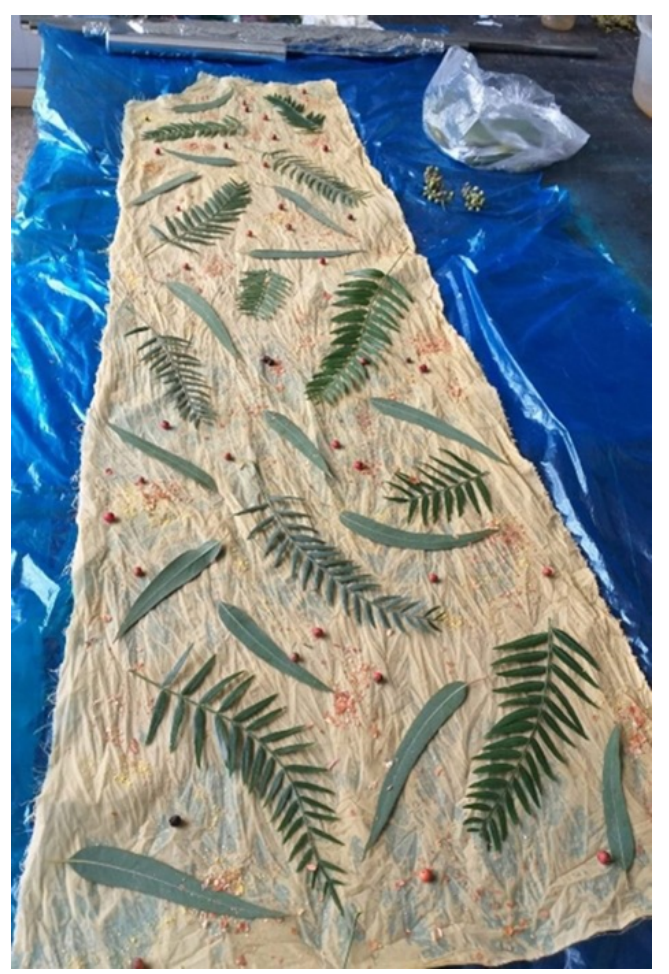

Şekil 7. a) Tasarım 4, bitkilerin kumaş üzerine yerleşimi, Özge Özen, 2019. 


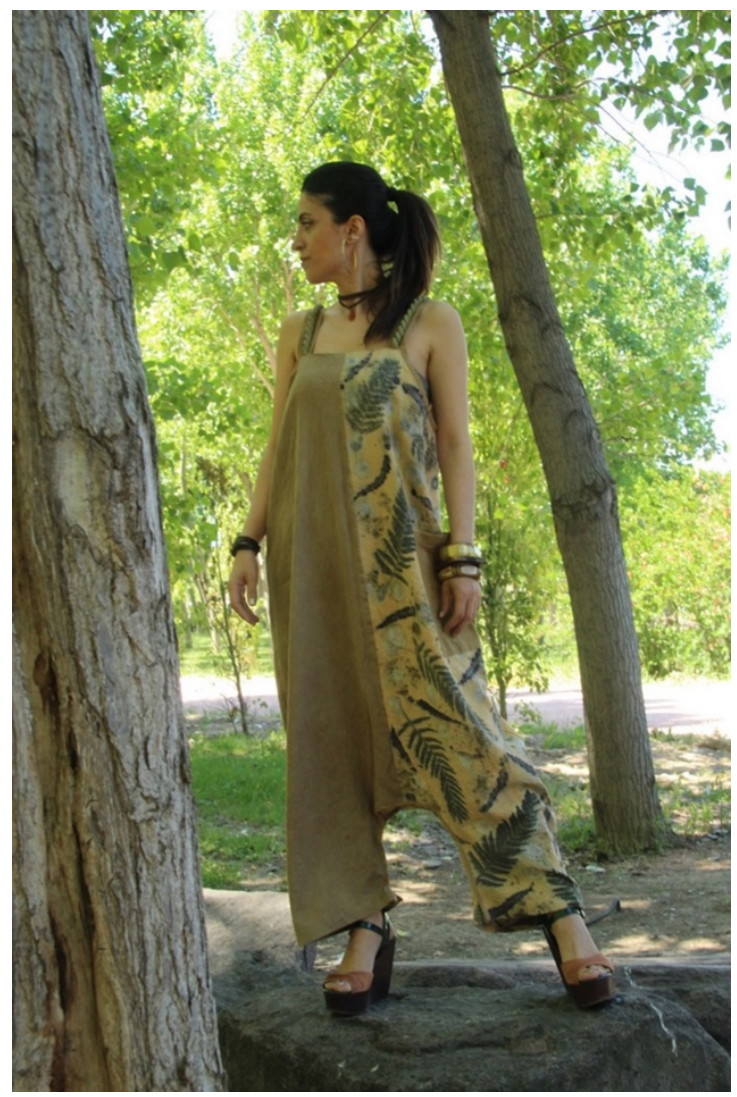

Şekil 7. b) Tasarım 4, tulum tasarımının önden görünümü, Özge Özen, 2019.

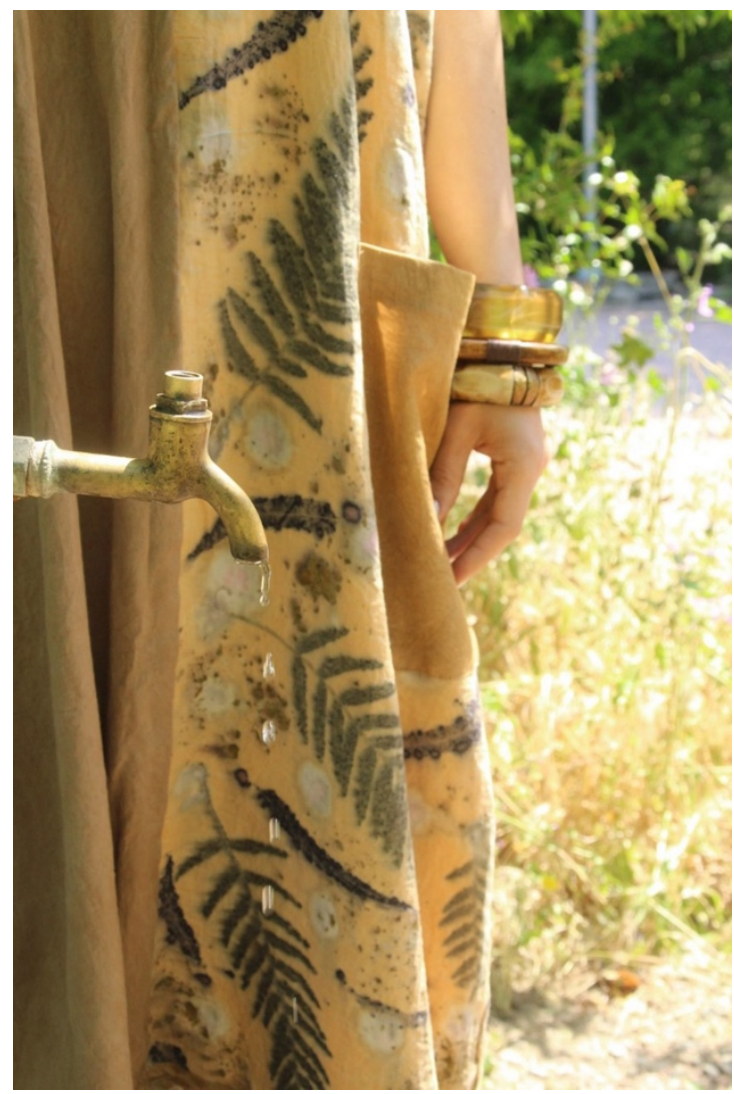

Şekil 8. Tasarım 4, tulumun detay görünümü, Özge Özen, 2019. 
Tasarım 5: Bu tasarımda Tablo 1' deki Deneme 2 reçetesine göre elbiseye ait 325 g kumaş kök boya ile pembe renkte boyanmıştır. Daha sonra, eko baskı işlemi Tablo 2' deki Tasarım 5' de belirtildiği şekilde uygulanmıştır. Elbise tasarımının uygulama sonucu ve detayları görülmektedir (Şekil 9 ve Şekil 10a-b).

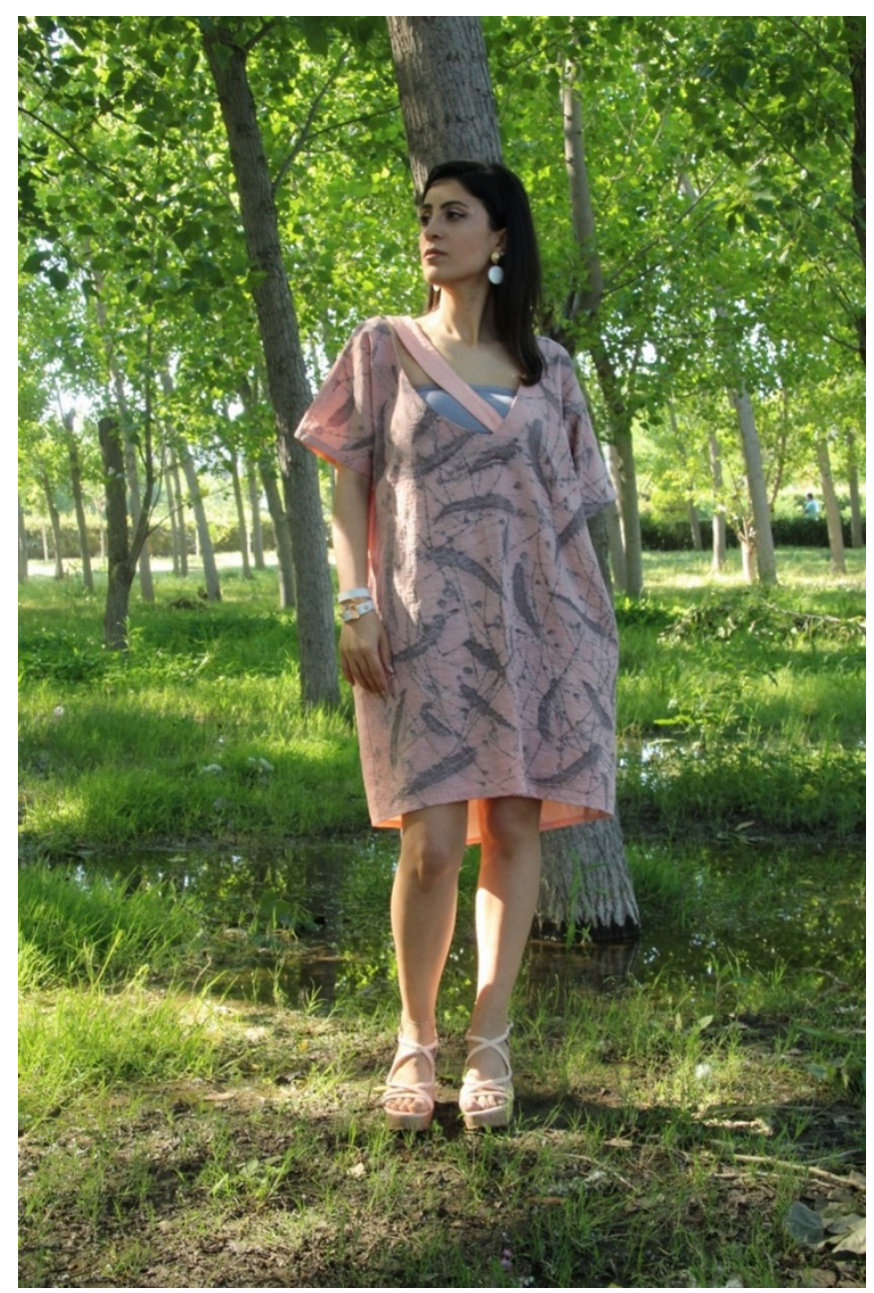

Şekil 9. Tasarım 5, elbisenin ön görünümü, Özge Özen, 2019.

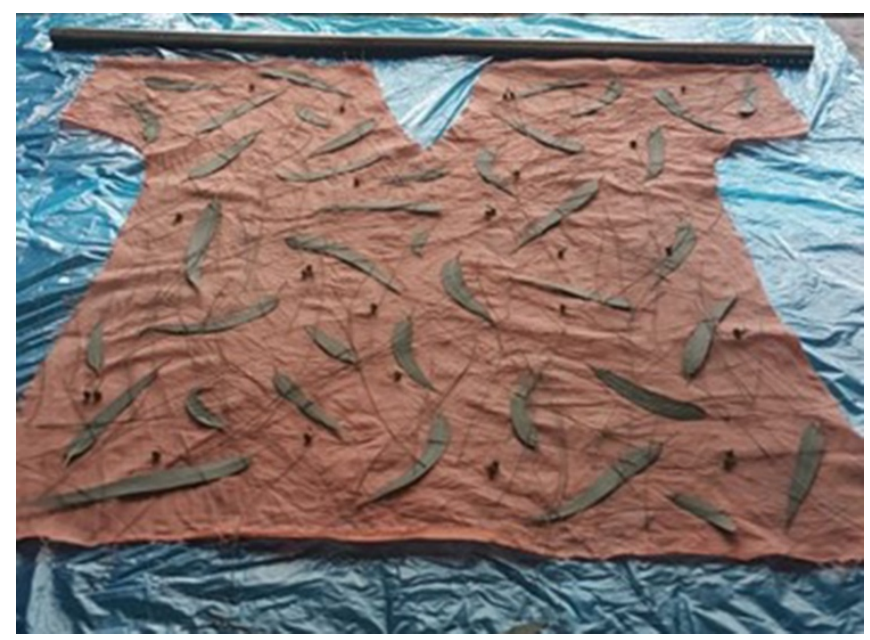

Şekil 10. a) Tasarım 5, kumaş üzerine bitkilerin belirlenen düzene göre yerleştirilmesi, Özge Özen, 2019. 


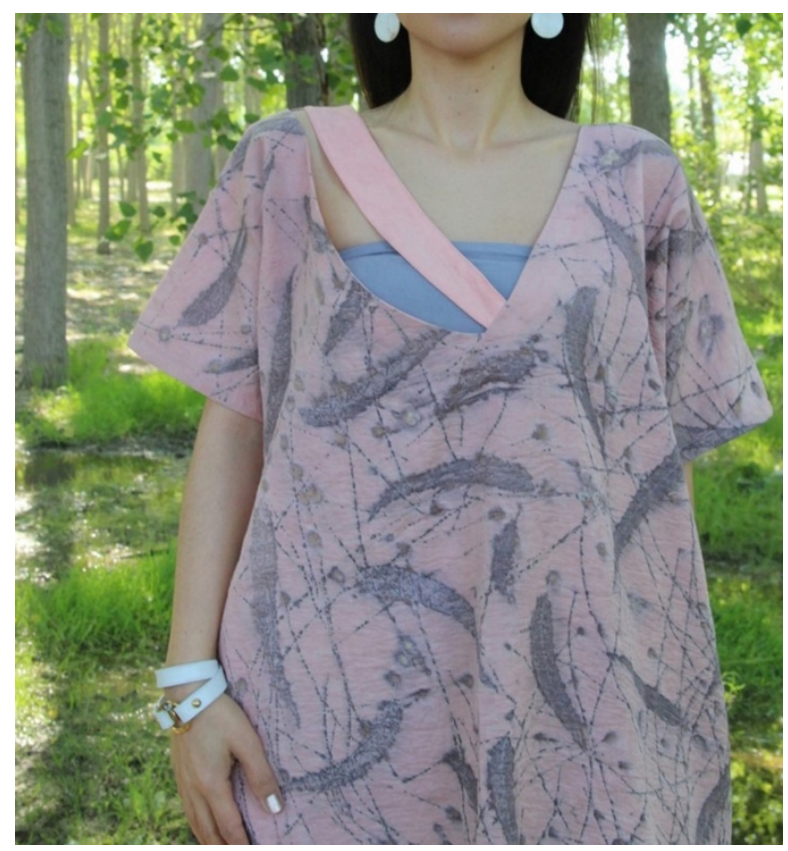

Şekil 10. b) Tasarım 5, elbisenin detay görünümü, Özge Özen, 2019.

Tasarım 6: Bu tasarımda Tablo 1' deki Deneme 5 reçetesine göre cekete ait 220 g kumaş nar kabuğu ile boyanarak hardal sarısı rengi elde edilmiştir. Eko baskı işlemi Tablo 2' deki tasarım 6'da belirtildiği şekilde yapılmıștır. Ceket tasarımının uygulama sonucu ve detayları Şekil 11 ve Şekil 12' de görülmektedir.

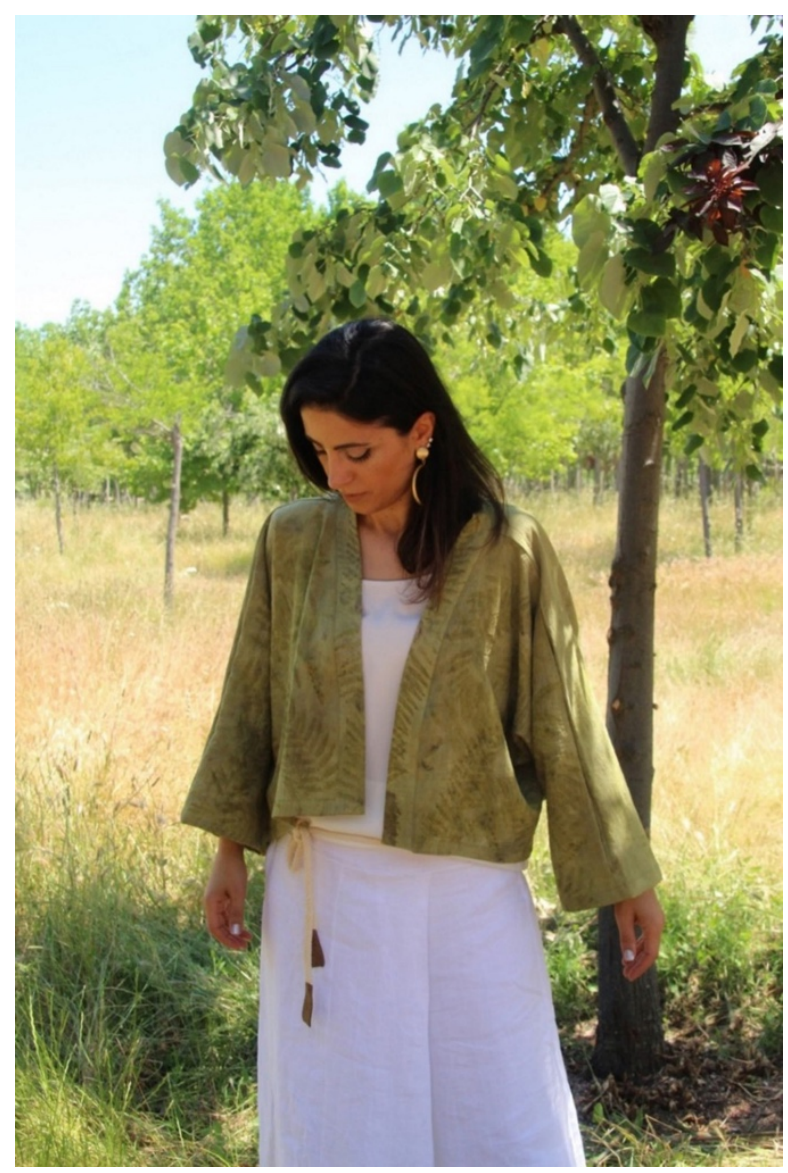

Şekil 11. Tasarım 6, ceketin ön görünümü, Özge Özen, 2019. 


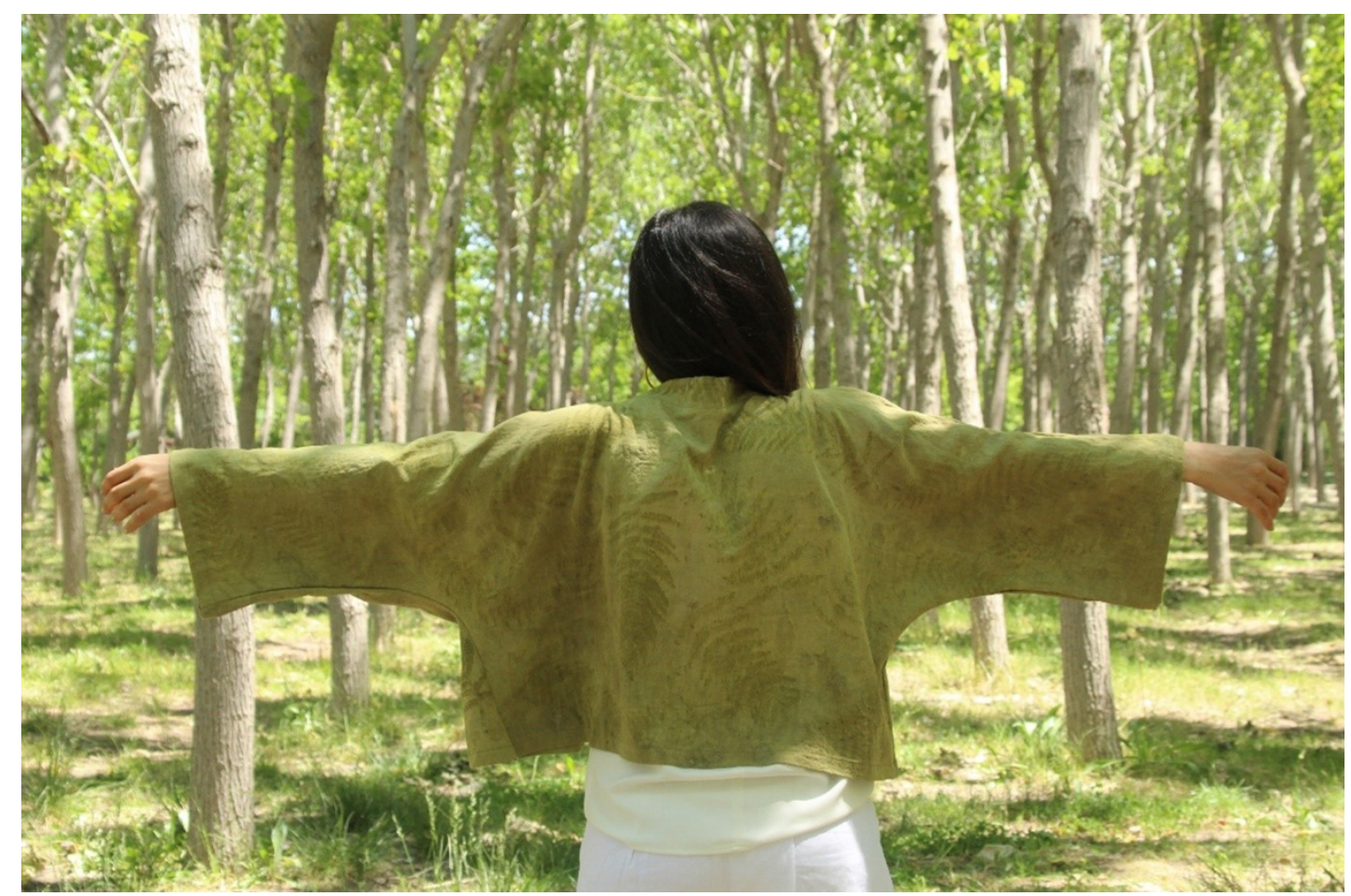

Şekil 12. Tasarım 6, ceketin arka görünümü, Özge Özen, 2019.

\section{Sonuç}

Farklı tasarımcı ve uygulayıcılar tarafından genelde yün, ipek gibi protein esaslı kumaşlara uygulanan eko baskı tekniği, bu çalışmada rejenere selüloz esaslı insan yapısı ve çevre dostu bir lif olan Tencel ${ }^{T M}$ Lyocell kumaş üzerinde çalışllarak bitkilerin doku, iz ve renklerinin kumaşa aktarılması sağlanmıştır. Doğal boyama ve eko baskıda yün, ipek gibi protein esaslı liflerle tatmin edici sonuçlar alınabildiği şeklindeki genel kanının aksine yapay bir lif ile de başarılı sonuçlar elde edilebildiği görülmüştür. Gerek renk koyuluğu, parlaklığı gerekse desen netliği açısından en güzel sonuçların alınmasında reçete optimizasyonu yani en iyi/uygun madde miktarları ve uygulama koşullarının (sıcaklık, süre, bitkilerin kullanım şekli, bağlama şekli, kumaşın sarıldığı borunun cinsi, fiksaj vd.) saptanması çok önemli olmaktadır. Zira tek bir etkenin bile değiştirilmesi ile tamamen farklı ve özgün başka bir tasarım elde etmek mümkün olabilmektedir. Yapılan çalışma sonucunda, en iyi etkiyi veren koşullar tespit edilmiş, kumaş yüzeyinde güzel renkler, bitki ve doku izleri başarılı bir şekilde elde edilmiştir.

Sürdürülebilir ve çevre dostu bir yaklaşımla, doğanın dengesini bozmayan doğal malzemelerle yapılan deneysel çalışmalar ışığında elde edilen doğal boyama reçeteleri ve eko baskı tekniği giysiler üzerinde uygulanarak her biri kendine özgü ve tekrarı olmayan tasarım çalışmaları yapılarak bir giysi koleksiyonu oluşturulmuştur. Bu bağlamda tasarıma ekolojik bir katkı sağlanmaya çalıșılmıștır. Gelecek kuşaklara daha yaşanabilir bir dünya bırakabilmek için yenilenebilir doğal kaynakların doğru kullanımı ve dünyanın ekolojik dengesini korumak hedeflenmelidir.

\section{Teşekkür}

Bu çalışmanın bir kısmı diploma projesi kapsamında gerçekleștirilmiștir. Tencel ${ }^{T M}$ Lyocell kumaş temini konusunda çok değerli desteklerinden ötürü Lenzing firması (Lenzing AG-Avusturya) Tekstil Proje Müdürü Dr. Hale Bahar Öztürk'e teşekkür ederiz.

\section{Kaynakça}

Adeel, S., Ghaffar, A., Mustaan, M. A., Rafi, S. \& Salman, M. (2018). Animal based natural dyes: A short review. In Yusuf, M. (Ed), Handbook of renewable materials for coloration and finishing (p. 41-74), USA: Scrivener Publishing, Wiley. 
Adeel, S., Azeem, M., Iqbal, N., Rafi, S., Salman, M. \& Zuber, M. (2018). Resurgence of natural dyes: Ideas and technologies for textile dyeing. In Shahid, M., Chen, G. and Tang, R. C. (Eds.), Handbook of textile coloration and finishing (p. 3-27), USA: Studıum Press LLC.

Adeel, S., Rehman, F. U., Rafi, S., Zia, K. M. \& Zuber, M. (2019). Environmentally friendly plant-based natural dyes: Extraction methodology and applications. In Ozturk, M. and Hakeem, H. R. (Eds.), Plant and human health, volume 2: Phytochemistry and molecular aspects (p. 383-415), Switzerland: Springer.

Adeel, S., Amin, N., Arif, S., Azeem, M., Batool, F., Habib, N. and Rehman, F. U. (2020). Microwave-assisted eco-dyeing of bio mordanted silk fabric using cinnamon bark (Cinnamomum Verum) based yellow natural dye. Sustainable Chemistry and Pharmacy, 17, p. 1-8. doi: 10.1016/j.scp.2020.100306

Adeel, S., Amin, N., Salman, M., Usama, M. and Zahoor, A. F. (2020). An insight into herbal-based natural dyes: Isolation and applications. In Pandit, P., Ahmed, S., Singha, K. and Shrivastava,S. (Eds.), Recycling from waste in fashion and textiles: A sustainable and circular economic approach (p. 423-456), USA: Scrivener Publishing, Wiley.

Adeel, S., Amin, N., Ahmad, T., Batool, F. and Hassan, A. (2020). Sustainable isolation of natural dyes from plant wastes for textiles. In Pandit, P., Ahmed, S., Singha, K. and Shrivastava,S. (Eds.), Recycling from waste in fashion and textiles: A sustainable and circular economic approach (p. 363-390), USA: Scrivener Publishing, Wiley.

Akpınarlı, H. F. ve Tambaş, C. (2019). Pamuklu-ipekli kumaşlara ekolojik baskı uygulaması ve haslık düzeylerinin belirlenmesi. Ídil Sanat ve Dil Dergisi, 62, s. 1295-1311. doi: 10.7816/idil-08-62-05

Akar, E. and Bulut, M. O. (2012). Ecological dyeing with some plant pulps on woolen yarn and cationized cotton fabric. Journal of Cleaner Production, 32, s. 1-9. doi: 10.1016/j.jclepro.2012.03.010

Arğun, N. F., Çolak, S.M. and Kaygusuz, M. (2020). Ecological printing: Surface design of leathers tanned with different tanning materials. In İrkin R. (Ed.), Academic studies in engineering II (p. 216-234), Ankara: Gece Kitaplığı.

Aydoğan B., Atak, O., Bilge, G. ve Erdem, R., M. (2018). İpek kumașların bitki yaprakları ile bölgesel desenlendirilmesi.Fen Bilimleri Enstitüsü Dergisi,22(2), s. 1058-1065. doi: $10.19113 /$ sdufbed.88199

Alvin, M. \& Wirawan, B. D. S. (2019). Teknik pewarnaan alam eco print daun ubi dengan penggunaan fiksator kapur, tawas dan tunjung. Jurnal Litbang Kota Pekalongan, 17, 1-5.

Akgümüş, D., Çay, A., Çelik, P. ve Eser, B. (2016). Tekstil ve konfeksiyon sektöründe sürdürülebilirlik ve geri dönüşüm olanakları. Tekstil ve Mühendis, 23(101), 43-60.

Ayvaz, K. M. ve Can, Ö. (2017). Tekstil ve modada sürdürülebilirlik. Akademia Doğa ve İnsan Bilimleri Dergisi, 3(1), 110-119.

Bilir, M. Z. (2018). Ekolojik boyama esaslı çok renkli yüzey tasarımı. yedi: Sanat, Tasarım ve Bilim Dergisi, (20), 63-73.

Basak, S., Chattopadhyay, S. K. \& Samanta, K. K. (2014). Eco-friendly coloration and functionalization of textile using plant extracts. In Muthu, S. S. (Ed.), Roadmap to sustainable textiles and clothing: Environmental and social aspects of textiles and clothing supply chain (p. 263-287), Singapore: Springer.

Can, D. İ. (2016). Giyilebilir sanat'ta eko boyama-baskı teknikleri ve uygulamaları (Doktora tezi). Süleyman Demirel Üniversitesi Güzel Sanatlar Enstitüsü, Isparta.

Çermikli, M. A. (2019). Ekolojik baskılar ve tekstil yüzeylerde uygulanması (Yüksek lisans tezi). Mimar Sinan Güzel Sanatlar Üniversitesi Güzel Sanatlar Enstitüsü, İstanbul.

Dartono, F. A., Herlina, M. S. \& Setyawan, S. (2018). Eksplorasi eco printing untuk produk sustainable fashion. Ornamen Jurnal Kriya Seni ISI Surakarta, 15(2), 118-130.

Elahi, A., Ghoranneviss, M. \& Shahidi, S. (2016). Clinical surface modification process using the nitrogen plasma and its anti-bacterial efficiency. Journal of X-ray Science and Technology, 24(6), p. 893-900. doi:10.3233/XST-160599 
Guesmi, A., Hamadi, N. B., Ladhari, N., Msaddek, M. and Sakli, F. (2013). First application of chlorophyll-a as biomordant: sonicator dyeing of wool with betanin dye. Journal of Cleaner Production, 39, p. 97104. doi: 10.1016/j.jclepro.2012.08.029

Ghoranneviss, M., Anvari, A., Motaghi, Z., Shahidi, S., Šlamborová, I. and Wiener, J. (2011). Influence of plasma sputtering treatment on natural dyeing and antibacterial activity of wool fabrics. Progress in Organic Coatings, 70(4), p. 388-393. doi: 10.1016/j.porgcoat.2010.11.017

Ghoranneviss, M., Shahidi, S. and Wiener, J. (2015). Improving synthetic and natural dyeability of polyester fabrics by dielectric barrier discharge. Journal of Plastic Film \& Sheeting, 31(3), p. 286-308. doi:10.1177/8756087914567013

Gürcüm, B. H., ve Yüksel, C., (2011). Moda sektörünü "yavaşlatan" eğilim: Eko moda ve moda'da sürdürülebilirlik. Akdeniz Sanat Dergisi, 4(8).

Haque, A., Farzana, N., Hussain, M., Smriti, S. A. \& Siddiqa, F. (2018). Kinetic study of curcumin on modal fabric. Tekstilec, 61(1), 27-32.

Husna, F. (2016). Eksplorasi teknik eco dyeing dengan tanaman sebagai pewarna alam. E-Proceeding of Art \& Design, 3(2), 280-293.

Hou, X., Chen, X., Cheng, Y., Xu, H., Chen, L. \& Yang, Y. (2013). Dyeing and UV-protection properties of water extracts from orange peel. Journal of Cleaner Production, 52, p. 410-419. doi: 10.1016/j.jclepro.2013.03.004

Haji, A., Mehrizi, M. K. \& Sharifzadeh, J. (2016). Dyeing of wool with aqueous extract of cotton pods improved by plasma treatment and chitosan: Optimization using response surface methodology. Fibers and Polymers, 17(9), p. 1480-1488. doi:10.1007/s12221-016-6457-0

Haji, A., Nasiriboroumand, M. \& Qavamnia, S. S. (2018). Cotton dyeing and antibacterial finishing using agricultural waste by an eco-friendly process optimized by response surface methodology. Fibers and Polymers, 19(11), p. 2359-2364. doi:10.1007/s12221-018-8657-2

Haji, A. (2020a). Application of D - optimal design in the analysis and modelling of dyeing of plasma treated wool with three natural dyes. Coloration Technology, 136(2), p. 137-146. doi:10.1111/cote. 12445

Haji, A. (2020b). Natural dyeing of wool with henna and yarrow enhanced by plasma treatment and optimized with response surface methodology. The Journal of the Textile Institute, 111(4), p. 467475. doi:10.1080/00405000.2019.1642710

Haji, A. \& Naebe, M. (2020). Cleaner dyeing of textiles using plasma treatment and natural dyes: A review. Journal of Cleaner Production, 265, p. 1-13. doi: 10.1016/j.jclepro.2020.121866

Heriningsih, S., Mardiana, T. and Warsiki, A. Y. N. (2020). Community development training with eco-print training wukirsari village, sleman district, Indonesia. International Journal of Computer Networks and Communications Security, 8(4), 32-36.

Ikhsani, N. \& Yulistiana, M. PSDM. (2020). Penerapan desain motif bunga pada scarf menggunakan teknik eco printing. Jurnal Tata Busana, 9(2), 57-64.

İşmal, Ö. E. ve Yıldırım, L. (2011). Tekstil tasarımında çevre dostu yaklaşımlar. Akdeniz Sanat Dergisi, 4(8), 9-13.

İşmal, Ö. E., \& Yıldırım, L. (2012). Almond shell as a natural colorant. Indian Journal of Fibre \& Textile Research, 37(4), 358-363.

İşmal, Ö. E. (2014). A route from olive oil production to natural dyeing: Valorisation of prina (Crude olive cake) as a novel dye source. Coloration Technology, 130(2), 147-153.

İşmal, Ö. E., Özdoğan, E. ve Yıldırım, L. (2014). Use of almond shell extracts plus biomordants as effective textile dye. Journal of Cleaner Production, 70(1), 61-67.

İşmal, Ö. E., Özdoğan, E. ve Yıldırım, L. (2015). Valorisation of almond shell waste in ultrasonic biomordanted dyeing: Alternatives to metallic mordants. The Journal of The Textile Institute, 106(4), 343-353.

İșmal, Ö. E. (2016). Patterns from nature: Contact printing. Journal of the Textile Association, 77(2), 81-91. 
İşmal, Ö. E. (2017). Greener natural dyeing pathway using a by-product of olive oil; prina and biomordants. Fibers and Polymers, 18(4), 773-785.

İşmal, Ö. E. and Yıldırım, L. (2019a). An overview of faba bean: Utilisation of husks in natural dyeing. International Journal of Clothing Science and Technology, 32(2), 188-196.

İşmal, Ö. E. and Yıldırım, L. (2019b). Banana peel in dyeing of polyamide/elastane blend fabric. Research Journal of Textile and Apparel, 23(2), 124-133.

İşmal, Ö. E. (2019). Doğal boya uygulamalarının değişen yüzü ve yenilikçi yaklaşımlar. yedi: Sanat, Tasarım ve Bilim Dergisi, (22), 41-58.

İşmal, Ö. E., Sağduyu, B. G. and Yıldırım, L. (2019). Creation of unique designs through resist dyeing with natural dyes. Journal of the Textile Association, September-October, 177-185.

Jeong, I. S. \& Kang, K. Y. (2017). A study on scarf design using eco printing-focused on the researcher's works. The Journal of the Korea Contents Association, 17(11), 221-228.

Karaboyacı, M. (2014). Recycling of rose wastes for use in natural plant dye and industrial applications. The Journal of The Textile Institute, 105(11), p. 1160-1166. doi: 10.1080/00405000.2013.876153

Karaboyacı, M. and Uğur, Ş. S. (2014). Ecological wool dyeing with pulps of lavender, broom, and red wine. The Journal of The Textile Institute, 105(8), p. 821-827. doi: 10.1080/00405000.2013.855379

Maharani, A. (2018). Motif dan pewarnaan tekstil di home industry kaine art fabric: Ecoprint natural dye. Pend. Seni Kerajinan-S1 (e-Craft), 7(4), 383-394.

Moazzenchi, B. \& Shahidi, S. (2019). Comparison between mordant treatment and plasma sputtering on natural dying and uv protection properties of wool fabric. Fibers and Polymers, 20(8), p. 1658-1665. doi:10.1007/s12221-019-2040-9

Mutmainah, S. \& Wahyuni, T. S. (2020). Karakteristik karya ecoprint natural dye pada kulit di rumah batik hardini papar-kediri. Jurnal Seni Rupa, 8(2), 194-207.

Mangır, A. F. (2016). Sürdürülebilir kalkınma için yavaș ve hızlı moda. Selçuk Üniversitesi Sosyal Bilimler Meslek Yüksekokulu Dergisi, 19[41. Yıl Özel Sayısı], 143-154.

Nurcahyanti, D. \& Septiana, U. (2018). Handmade eco print as a strategy to preserve the originality of Ria Miranda's designs in the digital age. Mudra Jurnal Seni Budaya, 33(3), 395-400.

Nuryawan, A. (2020). Eco-print on recycle paper and fabric as main products of business development program of intellectual property campus of universitas sumatera utara: Eco-print on recycle paper and fabric. Journal of Saintech Transfer, 3(1), 1-11.

Nissa, R. R., Pressinawangi, K. P. \& Widiawati, D. (2014). Eksplorasi teknik ecoprint dengan menggunakan limbah besi dan pewarna alami untuk produk fashion. Craft, 3(1), 1-7.

Odabaşı, S. (2016). Sürdürülebilir moda döngüsünde moda tasarımcısının rolü (Yüksek lisans tezi). Anadolu Üniversitesi Fen Bilimleri Enstitüsü, Eskişehir.

Odabaşı, S. ve Şahin, Y. (2018). Sürdürülebilir kalkınmada moda tasarımcısının rolüne yönelik alanyazın incelemesi. Uluslararası Yönetim Íktisat ve İşletme Dergisi, 14(2), 413-425.

Ramadhan, M. S. \& Salsabila, B. (2018). Eksplorasi teknik eco print dengan menggunakan kain linen untuk produk fashion. eProceedings of Art \& Design, 5(3), 2277-2292.

Türkmen, N. (2011). Sürdürülebilir bir tekstil endüstrisi için "yavașlık" ve alternatif üretim modelleri. Akdeniz Sanat Dergisi, 4(8).

Tencel $^{\mathrm{TM}}$. (t.y.). Sustainability. Erişim adresi: https://www.tencel.com/sustainability 